\title{
Azavinylidenephosphoranes: a new class of cyclic push-pull carbenes
}

\author{
Florie Lavigne, ${ }^{[a]}$ Aimée El Kazzi, ${ }^{[a]}$ Yannick Escudié, ${ }^{[a]}$ Eddy Maerten, ${ }^{*[a]}$ Tsuyoshi Kato, ${ }^{[a]}$ \\ Nathalie Saffon-Merceron, ${ }^{[b]}$ Vicenç Branchadell, ${ }^{[c]}$ Fernando P. Cossío[d] and Antoine \\ Baceiredo*[a]
}

Dedication ((optional))

\begin{abstract}
The synthesis of a novel family of cyclic push-pull carbenes, namely azavinylidene phosphoranes is described. The methodology is based on a formal [3+2] cycloaddition between terminal alkynes and phosphine-imines followed by an oxidation / deprotonation step. Carbenes $\mathbf{6}$, obtained by simple deprotonation, exhibit typical transient carbene reactivity like intramolecular $\mathrm{C}-\mathrm{H}$ insertion reaction and a pronounced ambiphilic character exemplified by $[2+1]$ cycloaddition with electron poor methyl acrylate. Due to the cyclic structure, carbenes 6 also exhibit an excellent
\end{abstract}

coordination ability toward transition metals. $\mathrm{Rh}(\mathrm{I})$-complex 10 was obtained in excellent yield and fully characterised by multinuclear NMR spectroscopy and X-ray crystallography. The corresponding $\mathrm{Rh}(\mathrm{I})$-carbonyl complex was also prepared indicating that carbenes 6 belong to the strongest $\sigma$-donating ligands to date. DFT calculations confirmed the high $\sigma$-donation ability of $\mathbf{6}$ and their classification as pushpull carbenes with a relatively small singlet-triplet energy gap of $\left(23.2\right.$ - $\left.24.3 \mathrm{kcal}_{\text {. }} \mathrm{mol}^{-1}\right)$.

\section{Introduction}

Since the isolation of the first stable carbenes in the late $80 \mathrm{~s}^{[1]}$ carbene chemistry has become a very active research field. ${ }^{\left[{ }^{[2]}\right.}$ The development of various stabilization modes afforded many useful tools like synthetic reagents, ${ }^{[3]}$ organocatalysts ${ }^{[4]}$ or ligands for transition metals in homogenous catalysis. ${ }^{[5]}$ The success in this latest application is mainly due to the peculiar properties of $\mathrm{N}$ heterocyclic carbenes (NHCs). ${ }^{[6]}$ Indeed, their strong $\sigma$-donor character and their excellent ability to bind metals afford not only

[a] $\operatorname{Dr}$ F. Lavigne, $\operatorname{Dr}$ A. El Kazzi, Y. Escudié, Dr E. Maerten, $\operatorname{Dr} T$. Kato, Dr A. Baceiredo

Université de Toulouse, UPS, and CNRS, LHFA UMR 5069, F31062 Toulouse Cedex 9 (France)

Fax: (+)33-561558204

E-mail: baceired@chimie.ups-tlse.fr maerten@chimie.ups-tlse.fr

[b] DrN. Saffon-Merceron

Université de Toulouse, UPS, and CNRS, ICT FR 2599, F-31062 Toulouse (France)

[c] Prof. V. Branchadell

Departament de Química, Universitat Autònoma de Barcelona, 08193 Bellaterra, Barcelona (Spain)

[d] Prof. F. P. Cossío

Departamento de Química Organica I

Universidad del País Vasco-Euskal Herriko Unibertsitatea Facultad de Química, P. K. 1072, San Sebastian-Donostia, (Spain)

Supporting information for this article is available on the WWW under http://www.chemeurj.org/ or from the author. robust but also very efficient organometallic catalysts. ${ }^{[7]}$ Interestingly, Bertrand offered new possibilities for structure modifications around the carbenic centre with the substitution of one amino group of NHCs by a $\mathrm{sp}^{3}$-hybridized carbon yielding to cyclic alkyl(amino)carbenes (CAACs) ${ }^{\left[{ }^{[8]}\right.}$ which are stronger $\sigma^{-}$ donating ligands than NHCs. Closely related, in 2008, Kawashima, Fürstner and Bertrand independently reported the synthesis of carbenes bearing an exocyclic ylide function adjacent from the carbene centre, namely the amino(ylidic)carbenes (N-YHCs), ${ }^{[9]}$ which are also excellent donor ligands. Moreover, CAACs present an extraordinary rich chemistry such as small molecules activation $\left(\mathrm{H}_{2}, \mathrm{NH}_{3}, \mathrm{CO}, \mathrm{P}_{4}\right),{ }^{[10]}$ and the corresponding transition metal complexes demonstrated very original catalytic properties (such as $\alpha$-arylation of ketones and aldehydes with aryl chlorides at room temperature, coupling enamines with terminal alkynes to yield allenes with loss of imines or hydroamination of alkynes and allenes with ammonia). ${ }^{[11]}$ These properties are the result of the particular structure of CAACs but also the consequence of a considerably reduced singlet-triplet energy gap (45.1 kcal.mol-1) when compared with NHCs ( 80 kcal. mol $\left.{ }^{-1}\right) .{ }^{[12]}$ There are only few examples of stable cyclic carbenes presenting a high electrophilic character. We can cite diamidocarbenes (DACs) showing an atypical $\mathrm{NHC}$ reactivity such as $\mathrm{C}-\mathrm{H}$ insertion, reversible coupling with carbon monoxide, and cyclopropanation reactions with a broad range of olefins. ${ }^{[13]}$ The original $\mathrm{N}$-Heterocyclic carbene $\left(\mathrm{N}_{\text {pyr }} \mathrm{HC}\right)$, featuring a bridgehead nitrogen atom, also shows interesting electrophilic properties especially as ligand for gold complexes, which are active catalysts in hydroamination of alkynes and allenes with hydrazine. ${ }^{[14]}$ Finally carbenes bearing an intracyclic ylide function, known as cyclic vinylidenephosphoranes (CVPs) also display strong electron-donating abilities and small $\mathrm{S} / \mathrm{T}$ energy gap, however, up to now, their development was limited because of restricted synthesis (Scheme 1). ${ }^{[15]}$ 
<smiles></smiles>

$\mathrm{NHC}$<smiles></smiles>

DAC

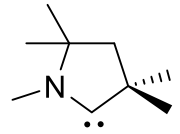

CAAC<smiles>CN1CC2CCCN(C2)C1</smiles>

$\mathrm{N}_{\text {pyr }} \mathrm{HC}$<smiles>CC1=C(C)N=P(C)(C)C1</smiles>

this work

CAVP
Scheme 1. Stable carbenes.

The peculiar structure of CVPs has retained our attention. Indeed, CVPs are cyclic heteroallenes containing a PC-ylidic bond and a CC-double bond, which can be formally described as cyclic push-pull carbenes (III) (Scheme 2).

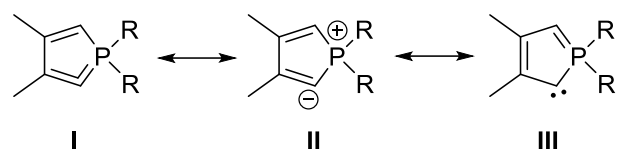

Scheme 2. Mesomeric structures of cyclic vinylidenephosphoranes.

Structural study revealed that the ylidic $\pi$-bond is extremely polarized due to a very weak interaction between the carbene lone pair and the phosphonio group (III). ${ }^{[15 b]}$ As a consequence, the carbene lone pair is fully available for coordination to transition metals, explaining why this cyclic carbene was found to be a strongly nucleophilic ligand. In addition, because of the substitution pattern of CVPs, this carbene presents a considerably reduced S/T energy gap $\left(32.4 \mathrm{kcal} . \mathrm{mol}^{-1}\right) \cdot{ }^{[15 \mathrm{~b}]}$ Similarly to the case of Enders' carbene ${ }^{[16]}$ the introduction of a phosphazene fragment at the backbone, instead of the ylide function, should further increase the ambiphilic character of a new family of carbenes the cyclic azavinylidenephosphoranes (CAVPs).

As a part of our research program towards new push-pull carbenes ${ }^{[17]}$ herein, we report the synthesis, reactivity, and ligand properties of the first examples of cyclic azavinylidenephosphoranes (CAVPs) (Scheme 3).<smiles>[R][R]1([R])cc(C)c(C)n1</smiles>
II III

CAVP

Scheme 3. Mesomeric structures of cyclic azavinylidenephosphoranes.

\section{Results and Discussion}

\section{Synthesis}

With this framework in mind, we designed a general synthetic approach to cyclic azavinylidenephosphoranes. Our methodology, inspired by seminal results of Zeiss, ${ }^{[18]}$ is based on a formal [3+2] cycloaddition between phosphine-imine $\mathbf{1}$ and terminal alkynes 2 to afford five-membered cyclic phosphazenes 4 . An oxidation/deprotonation step using $\mathrm{CBr}_{4}$ gives the phosphonium salts 5 , which are the precursors of CAVPs (Scheme 4). The easy modification of phosphine-imine 1 substituents or / and acetylenic derivatives 2 should allow an easy modulation of the steric and electronic properties of the corresponding carbenes.

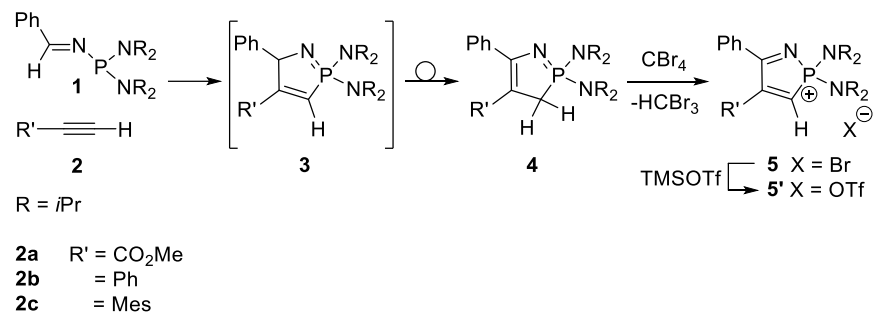

Scheme 4. Synthetic approach.

The study was initiated with phosphine-imine 1 bearing bis(diisopropylamino) groups on the phosphorus atom that will further bring an efficient kinetic stabilization of the carbenic centre. Three types of the acetylenic derivatives $\mathbf{2 a - c}$ were considered to balance the electrodeficiency of the carbenic centre by electronic or steric effects. The reaction is very substrate dependent, and can be performed at room temperature with an activated alkyne (2a) whereas xylene reflux is needed in the case of phenylacetylene (2b), and no reaction was observed in the case of mesitylacetylene (2c), even under drastic conditions, probably for steric reasons. The first formed phosphazenes 3 (observed by ${ }^{31} \mathrm{P}$ NMR in the case of $3 a$ ) rearrange to the thermodynamically more stable phosphazenes 4, via a 1,3-proton shift. Derivatives $\mathbf{4 a}$ and $\mathbf{4 b}$ were isolated in good yields $82 \%$ and $57 \%$ respectively, and fully characterized by multinuclear NMR spectroscopy. Selected spectroscopic data, in good agreement with previously described similar heterocycles, can be found in Table 1. ${ }^{[19]}$

Table 1. Selected spectroscopic data for $\mathbf{4 , 5}$ and $\mathbf{6}$ [Chemical shifts in ppm (coupling constants in Hertz)]

\begin{tabular}{|cccc|}
\hline & $\mathbf{4}$ & $\mathbf{5}$ & $\mathbf{6}$ \\
\hline \multirow{2}{*}{$\mathrm{P}\left\{{ }^{1} \mathrm{H}\right\}$} & 4a 74.6 & $\mathbf{5 a ~} 69.7$ & $\mathbf{6 a ~} 103.5$ \\
& 4b 72.6 & $\mathbf{5 b} 66.3$ & $\mathbf{6 b} 95.8$ \\
& 4a $2.99(10.4 \mathrm{~Hz})$ & $\mathbf{5 a} 9.81(28.9 \mathrm{~Hz})$ & - \\
${ }^{1} \mathrm{H}$ & 4b $3.08(10.5 \mathrm{~Hz})$ & $\mathbf{5 b} 8.83(30.6 \mathrm{~Hz})$ & - \\
& 4a $31.5(68.5 \mathrm{~Hz})$ & $\mathbf{5 a ~} 141.8(93.9 \mathrm{~Hz})$ & - \\
${ }^{13} \mathrm{C}$ & 4b $36.4(69.5 \mathrm{~Hz})$ & $\mathbf{5 b ~} 134.7(101.8 \mathrm{~Hz})$ & $\mathbf{6 b} 234.4(93.6 \mathrm{~Hz})$ \\
\hline
\end{tabular}

The oxidation-deprotonation sequence of phosphazenes 4 can be performed either in one step with $\mathrm{CBr}_{4}$ or in two steps using $\mathrm{Br}_{2}$ as oxidant then $\mathrm{NEt}_{3} / \mathrm{tBuOK}$ as base. Phosphonium salts $5 \mathbf{a}$ and $\mathbf{5 b}$ display single resonances $(\delta=69.7$ and $\delta=66.3 \mathrm{ppm})$ in ${ }^{31} \mathrm{P}$ NMR spectroscopy, and the characteristic ethylenic protons 
appear as doublets at low field in the ${ }^{1} \mathrm{H}$ NMR spectra $(\delta=9.81$ $\mathrm{ppm},{ }^{2} J_{\mathrm{HP}}=28.9 \mathrm{~Hz}$ and $\delta=8.83 \mathrm{ppm},{ }^{2} J_{\mathrm{HP}}=30.6 \mathrm{~Hz}$ ). In order to optimize the purification step and to obtain suitable crystals for an X-Ray diffraction analysis, anion metathesis was quantitatively performed with $\mathrm{Me}_{3} \mathrm{SiOTf}$ (Scheme 4). Both compounds 5'a,b, were obtained as colorless crystals from saturated solutions of $\mathrm{CH}_{2} \mathrm{Cl}_{2} / \mathrm{Et}_{2} \mathrm{O}$ or $\mathrm{CH}_{2} \mathrm{Cl}_{2} / \mathrm{THF}$, respectively, and the structures were confirmed by $\mathrm{X}$-ray diffraction analysis (Figure 1 and 2).

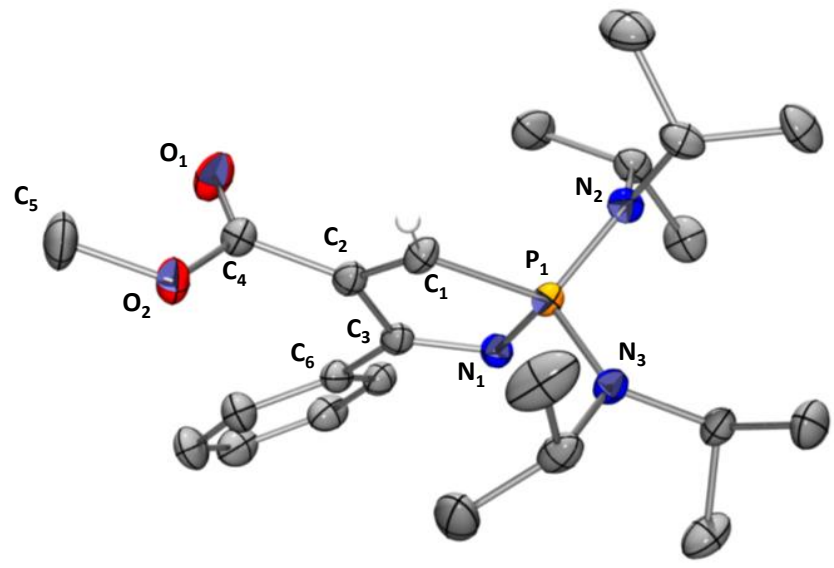

Figure 1. Molecular structure of phosphonium salt 5'a. Thermal ellipsoids were set at $30 \%$ probability. Hydrogen atoms, except the one on the 5-membered ring, and $\mathrm{TfO}^{-}$were omitted for clarity; selected bond lengths $[\AA]$ and angles $\left[{ }^{\circ}\right]$ : P1 N1: 1.690(2) ; P1-C1: 1.800(3) ; N1-C3: 1.302(4) ; C1-C2: 1.330(4) ; C2-C3: 1.516(4) ; C2-C4: 1.498(4) ; C3-C6: 1.468(4) ; P1-N2: 1.612(2) ; P1-N3: 1.616(2) ; C2-C1-P1: 105.9(2); N1-P1-C1: 96.45(12); C1-C2-C3: 112.9(2); N1C3-C2: 115.8(2); C3-N1-P1: 108.61(19).

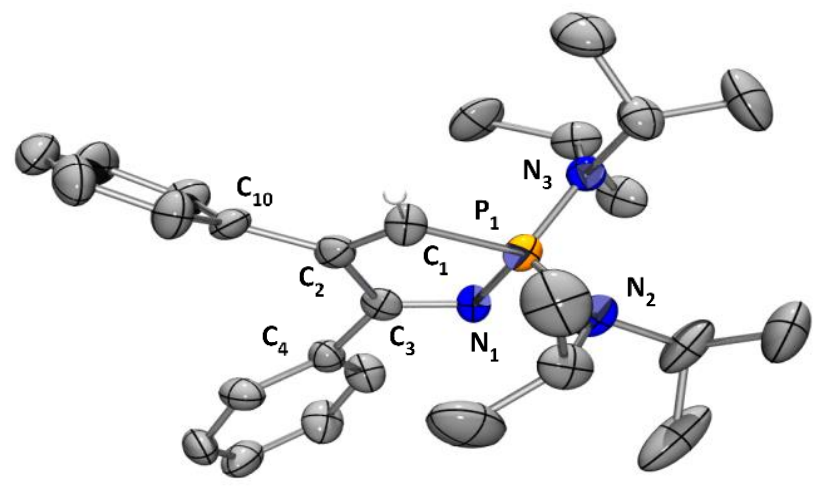

Figure 2. Molecular structure of phosphonium salt 5'b. Thermal ellipsoids were set at $30 \%$ probability. Hydrogen atoms, except the one on the 5-membered ring, and $\mathrm{TfO}^{-}$were omitted for clarity; selected bond lengths $[\AA]$ and angles $\left[{ }^{\circ}\right]$ : P1N1: 1.669(4) ; P1-C1: 1.778(5) ; N1-C3: 1.317(7) ; C1-C2: 1.342(7) ; C2-C3: 1.511(7); P1-N2: 1.611(4) ; P1-N3: 1.618(4) ; C2-C1-P1: 107.4(4); N1-P1-C1: 96.6(2); C1-C2-C3: 110.7(4); N1-C3-C2: 115.9(5); C3-N1-P1: 108.4(3).

Similarly to the previously described conjugated acid of CVP1 (cf Table 2), cyclic phosphonium salts 5'a,b show significant localized diene character with $\mathrm{C} 1 \mathrm{C} 2$ and $\mathrm{C} 3 \mathrm{~N} 1$ bonds which are typically short, respectively $1.342(7)$ and $1.317(7) \AA$, whereas $\mathrm{C} 2 \mathrm{C} 3$ bond length are in the range expected for a single bond. ${ }^{[15 \mathrm{~b}]}$

Scheme 5. Deprotonation of phosphonium salt 5'a,b.
Deprotonation of $\mathbf{5}^{\prime}$, was carried out in THF at low temperature $\left(-80^{\circ} \mathrm{C}\right)$ using non nucleophilic strong bases such as potassium hexamethyldisilazane (KHMDS) or mesityl lithium (Scheme 5). ${ }^{[20]}$ The formation the desired azavinylidenephosphoranes $\mathbf{6 a}$ and $\mathbf{6 b}$ was indicated in ${ }^{31} \mathrm{P}$ NMR spectroscopy by single resonances respectively at $\delta=103.5 \mathrm{ppm}$ and $\delta=95.8 \mathrm{ppm}$, reminiscent of the phosphorus chemical shift observed for CVP1 $\left(\delta=86.4 \mathrm{ppm}\right.$ in $\left.\mathrm{C}_{6} \mathrm{D}_{6}\right) .{ }^{[15 \mathrm{~b}]}$ Variabletemperature multinuclear NMR studies indicated that $\mathbf{6 a}$ was unstable and decomposed at low temperature $\left(-80^{\circ} \mathrm{C}\right)$. However, $\mathbf{6 b}$ is perfectly stable at low temperature $\left(\mathrm{T}<-15^{\circ} \mathrm{C}\right)$, and it can be

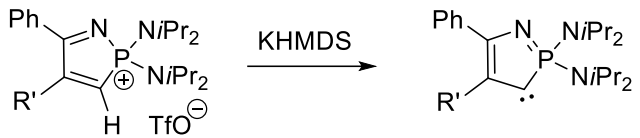

$$
\begin{aligned}
& \text { 5'a } \quad \mathrm{R}^{\prime}=\mathrm{CO}_{2} \mathrm{Me} \quad \mathbf{6 a , b} \\
& \text { 5'b } \quad \mathrm{R}^{\prime}=\mathrm{Ph}
\end{aligned}
$$

characterized by NMR spectroscopy. Of special interest, the characteristic ${ }^{13} \mathrm{C}$ NMR signal of the carbenic center appears as a low field doublet at $\delta=234.4 \mathrm{ppm}\left({ }^{1} J_{\mathrm{CP}}=96.3 \mathrm{~Hz}\right)$, in the typical area of NHC carbenic centres. Unfortunately, all our attempts to crystalize $\mathbf{6 b}$ were unsuccessful.

\section{Calculations}

In order to get a better insight into the structure and electronic nature of CAVPs, theoretical calculations have been performed. We have optimized the geometries of the phosphonium salts $\mathbf{5}^{\prime} \mathbf{b}$, and carbene $\mathbf{6 b}$ at the B3LYP level of calculation. The results obtained for $\mathbf{5}^{\mathbf{\prime}} \mathbf{b}$ are in excellent agreement with the experimental values shown in Figure 2, with mean absolute deviations of 0.014 $\AA$ for interatomic distances and $0.4^{\circ}$ for bond angles. ${ }^{[21]}$ According to the NBO method, the Lewis structure which gives the best description of the electronic structure of $\mathbf{6}$ is II (Scheme 3). ${ }^{[21]}$ Figure 3 shows the HOMO and LUMO of $6 \mathbf{b}$. The HOMO is localized on the carbenic center whereas the LUMO corresponds to the delocalized $\pi$-system. The energy level of the HOMO and the singlet-triplet energy gap were calculated for different CAVPs and CVPs (Table 2). The values obtained for the HOMO level of 6a-d are high, all these carbenes are more nucleophilic than NHCs. As expected, the HOMO levels of CAVPs are directly influenced by the inductive effect of R' group. In contrast, the $\mathrm{S} / \mathrm{T}$ energy gap calculated for carbenes 6a-d are very similar $\left(\sim 24 \mathrm{kcal}^{\mathrm{mol}}{ }^{-1}\right)$, much smaller than the value reported for the previously described CVP1. ${ }^{[15 b]}$ In order to understand the origin of this difference, we calculated the S/T energy gap of other CAVPs and CVPs. Comparing values obtained for CAVP1 and CVP2,3, it appears than both the nitrogen atom and the phenyl group at the backbone are needed to obtain a carbene showing a pronounced ambiphilic character.

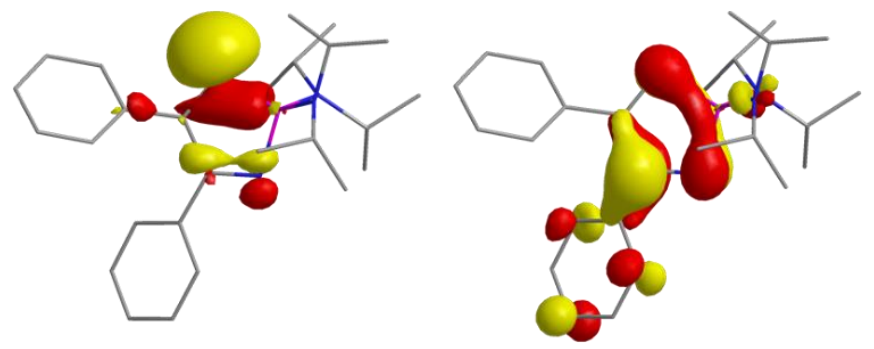

Figure 3. HOMO (left) and LUMO (right) of $6 \mathbf{b}( \pm 0.05$ contours) computed at the B3LYP/6-31G(d) level of calculation. 
Table 2. Calculated HOMO energy ( $E_{H}$, in eV), singlet-triplet energy gap ( $\triangle \mathrm{E}_{\mathrm{ST}}$, in $\mathrm{kcal}^{\mathrm{mol}}{ }^{-1}$ ), electrophilicity ( $\omega$, in Ev) and maximum saturation electronic charge $\left(\Delta N_{\max }\right.$, in a. u.), for various cyclic CAVPs and CVPs at the B3LYP/6$31 \mathrm{G}(\mathrm{d})$ level of calculation.

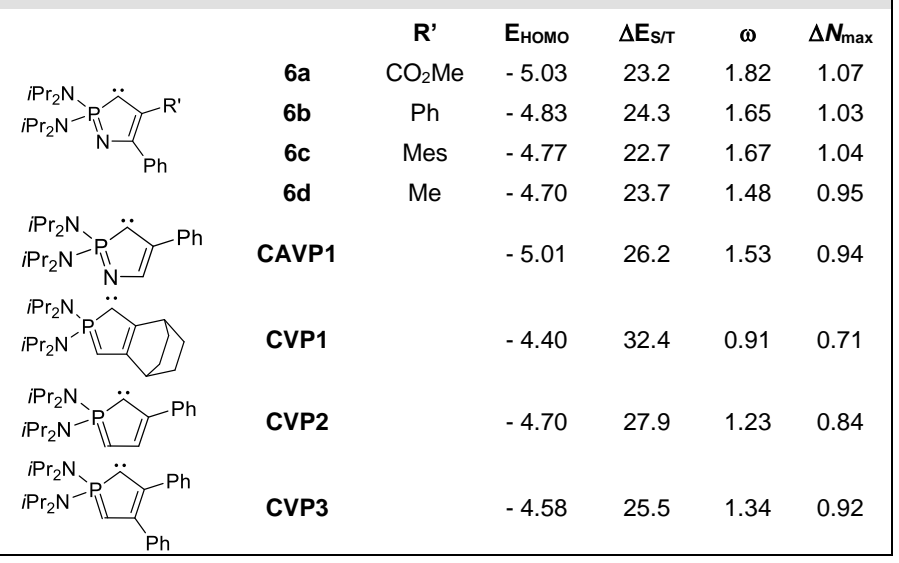

We have also computed the electrophilicity $\omega$ and the maximum saturation electronic charge $\Delta N_{\max }$ of each carbenic species 6a-d, CAVP1 and CVP1-3 (Table 2). The latter magnitude $\Delta N_{\max }$ is closely related to the number of electrons required to complete the octet of compounds gathered in Table 2. Thus, for an ideal carbene with non-interacting groups one would expect an approximate value $\Delta N_{\max }$ of $\approx 2.0$. In singlet $\mathrm{C}_{2 v}$-symmetric carbenes $\mathrm{CH}_{2}$ and $\mathrm{CCl}_{2}$ the computed values are 1.50 and $1.43 \mathrm{a}$. $\mathrm{u}$., the corresponding electrophilicities being 3.68 and $3.88 \mathrm{eV}$, respectively. ${ }^{[22]}$ Our results for compounds CVP1 and CVP2 show quite low $\omega$ and $\Delta N_{\max }$ values because of the efficient electronreleasing effect on the carbene moiety of the fused bicyclic ring and phenyl groups. Moreover, carbene $6 \mathbf{a}$ which combines a nitrogen atom at the backbone and an electron-withdrawing ester function exhibits the highest $\omega$ and $\Delta N_{\max }$ values (Table 2), in good agreement with its experimentally observed high reactivity (videinfra). Carbene $6 \mathbf{b}, \mathbf{c}$, which incorporate two vicinal non-coplanar aryl groups in the 1,2 $2 \lambda^{5}$-azaphosphole ring, represent a good compromise between relative stability and reactivity, with $\Delta N_{\max }$ value of ca. 1 a. u.

\section{Carbenic properties}

The reactivity of stabilized carbenes depends on the singlettriplet energy gap, and carbene $6 \mathbf{b}$ presenting a relatively small S/T gap of $24.3 \mathrm{kcal} . \mathrm{mol}^{-1}$ should exhibit an ambiphilic character and the reactivity of transient singlet carbenes.

The stability of carbenes 6 is strongly dependent on the nature of substituents. Indeed, $\mathbf{6 a}\left(\mathrm{R}^{\prime}=\mathrm{CO}_{2} \mathrm{Me}\right)$ decomposes at low temperature giving a complex mixture of products, whereas, 6b $\left(R^{\prime}=P h\right)$ is stable for days at $T<-15^{\circ} \mathrm{C}$. By increasing slowly the temperature to rt, carbene $\mathbf{6 b}$ undergoes a clean $\mathrm{C}-\mathrm{H}$ insertion, involving the phosphorus isopropyl substituent, affording the fused bi-cyclic structure 7 (Scheme 6). Phosphazene 7 was isolated as a colorless oil and fully characterized by multinuclear NMR spectroscopy. A single resonance at $\delta=66.6 \mathrm{ppm}$ is observed in the ${ }^{31} \mathrm{P}$ NMR spectrum. In the ${ }^{1} \mathrm{H}$ NMR spectrum, the inserted hydrogen atom appears as a doublet signal at $\delta=3.37 \mathrm{ppm}\left({ }^{2} J_{\mathrm{HP}}\right.$ $=12.0 \mathrm{~Hz}$ ), and the corresponding carbon atom resonates at $\delta=$ $61.9 \mathrm{ppm}$ as a doublet with a large coupling constant $\left({ }^{1} J_{\mathrm{CP}}=54.7\right.$ $\mathrm{Hz}$ ) in the ${ }^{13} \mathrm{C}$ NMR spectrum. The bicyclic structure could be confirmed by 2D HMBC experiments showing a strong ${ }^{3} \mathrm{~J}$ heteronuclear chemical shift correlation between the carbon alpha to the phosphorus and the two methyl groups of the fourmembered ring. ${ }^{13} \mathrm{C}$ NMR data are in good agreement with azaphosphetanes previously described in the literature. ${ }^{[23]}$

Usually alkenes react with singlet carbenes in a concerted fashion to give the corresponding cyclopropane products. ${ }^{[2 b]}$ In the case of carbene $6 \mathrm{~b}$ a clean reaction was observed with an electron poor olefin, methyl acrylate, at $-80^{\circ} \mathrm{C}$, affording the corresponding cyclopropane 8 (Scheme 6). Since the spiro phosphazene $\mathbf{8}$ slowly decomposes at room temperature, it was characterized by multinuclear NMR spectroscopy at low temperature.

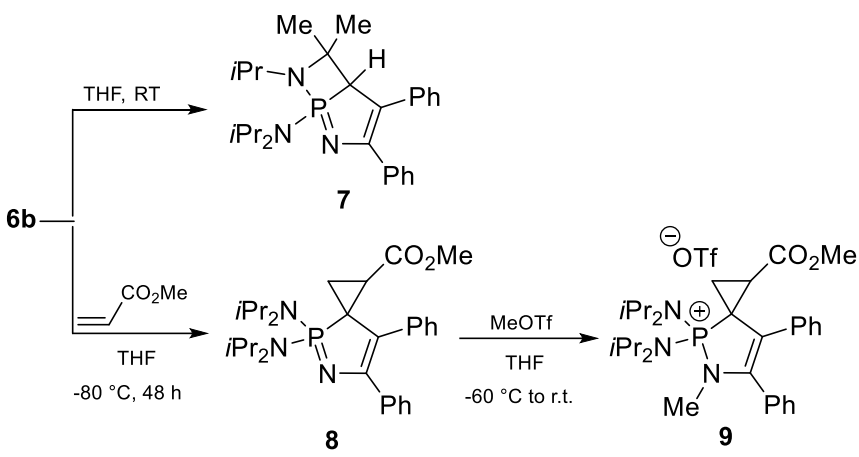

Scheme 6. Reactivity of carbene $6 \mathrm{~b}$ : $\mathrm{C}-\mathrm{H}$ insertion and cyclopropanation reactions.

A single resonance, in the ${ }^{31} \mathrm{P}$ NMR spectrum at $\delta=75.7 \mathrm{ppm}$ indicates a diastereoselective cyclopropanation reaction. The spiranic carbon atom resonates as a doublet at $\delta=37.3 \mathrm{ppm}$ in the ${ }^{13} \mathrm{C}$ NMR spectrum with a large coupling constant $\left({ }^{1} \mathrm{~J}_{\mathrm{CP}}=96.7 \mathrm{~Hz}\right)$ indicative of a direct $\mathrm{PC}$-connectivity. In addition the other two three-membered ring carbon atoms $\mathrm{CH}_{2}$ and $\mathrm{CH}$, appear also as doublets at $\delta=22.3\left({ }^{2} J_{\mathrm{CP}}=2.8 \mathrm{~Hz}\right)$ and $\delta=26.6\left({ }^{2} J_{\mathrm{CP}}=7.2 \mathrm{~Hz}\right)$, respectively. In the ${ }^{1} \mathrm{H}$ NMR spectrum the diastereotopic methylene protons give a multiplet at $\delta=1.42 \mathrm{ppm}$ and a doublet of doublet of doublets at $\delta=1.89 \mathrm{ppm}\left({ }^{2} \mathrm{JHH}_{\mathrm{HH}}=4.0 \mathrm{~Hz},{ }^{3} \mathrm{~J}_{\mathrm{HH}}=6.4 \mathrm{~Hz},{ }^{3} \mathrm{~J}_{\mathrm{HP}}=\right.$ $13.0 \mathrm{~Hz}$ ). The alpha proton of the ester function is located at $\delta=$ $2.10 \mathrm{ppm}$ (ddd, ${ }^{3} J_{\mathrm{HH}}=5.6 \mathrm{~Hz},{ }^{3} J_{\mathrm{HH}}=6.4 \mathrm{~Hz},{ }^{3} J_{\mathrm{HP}}=7.6 \mathrm{~Hz}$ ). Finally, the spiranic structure is clearly confirmed by $2 \mathrm{D} \mathrm{HMBC}$ experiments showing a strong heteronuclear chemical shift correlation between the 3-membered ring protons and the quaternary carbon alpha to the phosphorus atom. The instability of $\mathbf{8}$ is mainly due to the presence of the phosphazene function, which presents a strong nucleophilic character. Indeed, the addition of one equivalent of MeOTf, at low temperature, smoothly affords the air stable spiro phosphonium salts $\mathbf{9}$, which presents very similar NMR data to those of 8 (Scheme 6).

\section{Ligand properties}

Despite its thermal instability carbene $\mathbf{6 b}$ appears to be an efficient new ligand for transition metals. Indeed, mixing its precursor $5^{\prime} \mathbf{b}$, $\mathrm{KHMDS}$, and $[\mathrm{RhCl}(\mathrm{COD})]_{2}$ at $-80^{\circ} \mathrm{C}$, leads to the corresponding $\mathrm{Rh}(\mathrm{I})$-complex $\mathbf{1 0}$, in $71 \%$ yield, as a thermally and air stable red solid (M. P. $159-161^{\circ} \mathrm{C}$ ) (Scheme 7). In ${ }^{31} \mathrm{P}$ NMR, a signal at $\delta=80.9 \mathrm{ppm}$ appears as a doublet with a small Rh-Pcoupling constant $\left({ }^{1} \mathrm{JPRh}_{\mathrm{PRh}}=6.2 \mathrm{~Hz}\right.$ ). The formation of complex 10 can clearly be ascertained by ${ }^{13} \mathrm{C}$ NMR where the carbene center 
moves upfield, as is typical for this type of metal complexes, to $\delta=$ $195.8 \mathrm{ppm}\left(\mathrm{dd},{ }^{1} J_{\mathrm{CP}}=41.2 \mathrm{~Hz}\right.$ and ${ }^{1} J_{\mathrm{CRh}}=7.6 \mathrm{~Hz}$ ) confirming the direct connectivity between carbon and rhodium atoms. The structure of $\mathbf{1 0}$ was unambiguously established by an X-ray diffraction analysis (Figure 4). The P1C1C2 angle in $\mathbf{1 0}\left(101.1^{\circ}\right)$ is slightly narrower than the azavinylidenephosphorane precursor $\mathbf{5}^{\prime} \mathbf{b}\left(107.4^{\circ}\right)$. The rhodium-carbon bond length is typical for a single bond $(2.050 \AA)$, in the range of previously reported rhodium complexes $(1.94-2.10 \AA){ }^{[5 b]}$

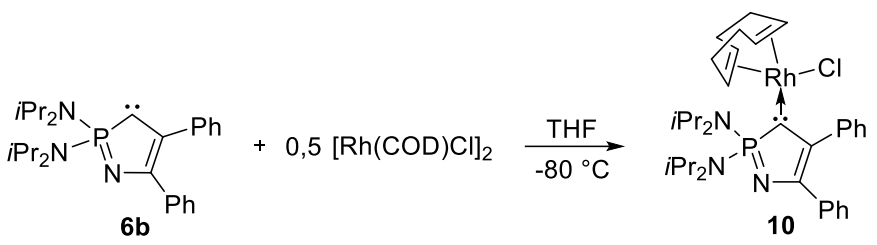

Scheme 7. Synthesis of $\mathrm{Rh}(\mathrm{I})$-complex 10

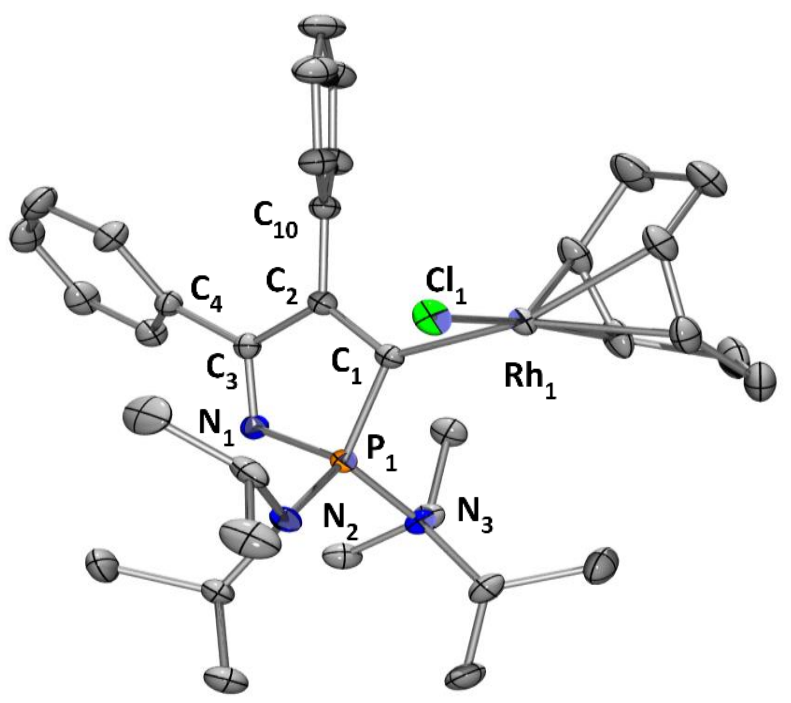

Figure 4. Molecular representation of rhodium complex 10. Thermal ellipsoids were set at $30 \%$ probability. Hydrogen atoms were omitted for clarity; selected bond lengths $[\AA]$ and angles [ $\left.{ }^{\circ}\right]$ : Rh1-C1: 2.050(2); C1-C2: 1.364(3); C2-C3: 1.499(3); C3-C4: 1.486(3); C2-C10: 1.484(3); Rh1-Cl1: 2.3999(1); P1-N2: 1.632(2); N1-C3: 1.301(3); P1-C1: 1.823(2); P1-N3: 1.638(2); P1-N1: 1.688(2); C1-Rh1-Cl1: 95.24(5); N2-P1-N3: 109.16(9); N1-P1-C1: 99.67(9); C3-N1-P1: 105.97(13); C2-C1-P1: 101.11(14); C2-C1-Rh1: 127.45(15); P1-C1-Rh1: 130.96(11); C1-C2-C3: 115.37(17); C10-C2-C3: 120.14(17); N1-C3-C2: 117.41(17).

The carbonyl stretching frequencies of cis- $\left[\mathrm{RhCl}(\mathrm{CO})_{2} \mathrm{~L}\right]$ complexes are recognized to give an excellent measure of the $\sigma$ donor vs $\pi$-acceptor properties of ligand L. ${ }^{[2]}$ The corresponding Rh-dicarbonyl complex 11 was easily prepared by bubbling carbon monoxide through a dichloromethane solution of $\mathbf{1 0}$ (Scheme 8). Monitoring the transformation by ${ }^{31} \mathrm{P}$ NMR spectroscopy, the gradual consumption of $\mathbf{1 0}$ with the concomitant formation of $\mathbf{1 1}$ was observed. Complex 11 exhibits a signal at $\delta=84.6 \mathrm{ppm}$ as a doublet $\left({ }^{2} J_{\mathrm{PRh}}=6.7 \mathrm{~Hz}\right)$ in ${ }^{31} \mathrm{P}$ NMR spectrum. The chelating carbon appears at $\delta=177.9 \mathrm{ppm}$ as a doublet of doublets $\left({ }^{1} \mathrm{JPP}_{\mathrm{CP}}=35.8 \mathrm{~Hz}\right.$ and ${ }^{1} J_{\mathrm{CRh}}=23.6 \mathrm{~Hz}$ ) in the ${ }^{13} \mathrm{C}$ NMR spectrum. In addition, two characteristic resonances were observed for the two carbonyls groups at $\delta=183.5 \mathrm{ppm}\left(\mathrm{d},{ }^{1} J_{\mathrm{CRh}}=74.2 \mathrm{~Hz}\right)$ and $\delta=185.4 \mathrm{ppm}$ (dd, ${ }^{3} J_{\mathrm{CP}}=10.4 \mathrm{~Hz}$ and ${ }^{1} \mathrm{~J}_{\mathrm{CRh}}=52.5 \mathrm{~Hz}$ ). The infrared spectrum shows the characteristic $\mathrm{CO}$ stretching frequencies with an average value of $2028 \mathrm{~cm}^{-1}$. This value highlights the strong $\sigma$ donation ability of $\mathbf{6 b}$, which is much stronger than NHCs, but remaining weaker than CVP1 probably because of the higher electrophilic character of $\mathbf{6 b}$ (Scheme 9). Computed scaled average carbonyl stretching frequencies for $\mathbf{1 1}$ was found to be $2025 \mathrm{~cm}^{-1}$, in excellent agreement with experimental values (see Scheme 9). The geometry of the complex of CVP1 with $\mathrm{Rh}(\mathrm{CO})_{2} \mathrm{Cl}$ was also optimized and the computed average $\mathrm{CO}$ stretching is $2018 \mathrm{~cm}^{-1}$. Finally, the electron donor character of $\mathbf{6 b}$ is also reflected in the natural atomic population analysis of complexes $\mathbf{1 0}$ and 11 which shows that the charge transferred from $\mathbf{6 b}$ to the metal fragment are 0.40 a.u. (10) and 0.46 a.u. (11).

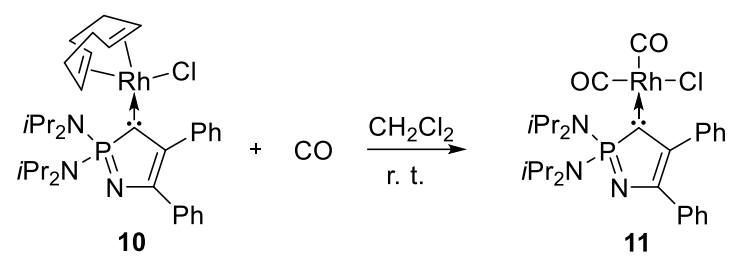

Scheme 8. Synthesis of $\mathrm{Rh}(\mathrm{I})$-complex 11.

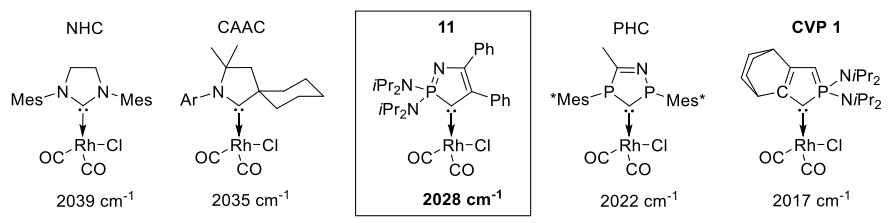

Scheme 9. Comparison of average IR band of $v(\mathrm{CO})$ in cis-[ $\left.\mathrm{RhCl}(\mathrm{CO})_{2} \mathrm{~L}\right] .[8,15 \mathrm{~b}, 25]$

\section{Conclusion}

We established an efficient new methodology to access to cyclic azavinylidenephosphoranes in three steps. The first example $\mathbf{6 b}$ was fully characterized by multinuclear NMR spectroscopy, and its chemical reactivity highlight a strong ambiphilic character exemplified by $\mathrm{C}-\mathrm{H}$ insertion or cyclopropanation reactions with electron-poor alkenes. This chemical behavior is in good agreement with calculations which predict a small S/T energy gap for this new family of carbenes. These cyclic push-pull carbenes also show an excellent ability to bind transition metal and their high $\sigma$-donor aptitude was established by analysis of IR-CO stretching frequencies of the corresponding $\mathrm{Rh}(\mathrm{I})$-carbonyl complexe 11. In addition, the use of these carbenes as ligand in asymmetric catalysis can be easily envisaged because of the presence of a potentially P-chiral centre adjacent to the carbenic centre that bring the chiral information as close as possible to the metallic centre and therefore hopefully lead to high stereoinduction. Development of new models using this methodology to increase their thermal stability is under active investigation.

\section{Experimental Section}

\section{General procedures}

All manipulations were performed under an inert atmosphere of argon by using standard Schlenk techniques. Dry and oxygen-free solvents were used. ${ }^{1} \mathrm{H},{ }^{13} \mathrm{C}$ and ${ }^{31} \mathrm{P}$ NMR spectra were recorded on Brucker Avance 400 or Avance 300 
spectrometers. ${ }^{1} \mathrm{H}$ NMR and ${ }^{13} \mathrm{C}$ NMR chemical shifts are reported in parts per million (ppm) relative to $\mathrm{Me}_{4} \mathrm{Si}$ as external standard. ${ }^{31} \mathrm{P} \mathrm{NMR}$ downfield chemical are expressed in ppm relative to $85 \% \mathrm{H}_{3} \mathrm{PO}_{4}$. IR spectra were recorded on a Varian 640-IR. Mass spectra were recorded on Hewlett Packard 5989A spectrometer.

Cyclic phosphazene 4b: Bis(diisopropylamino)phosphine imine 1 (16.7 g, 49.9 $\mathrm{mmol}$ ) was dissolved in $40 \mathrm{~mL}$ of xylene, and heated to reflux. Then a solution of phenylacetylene $\mathbf{2 b}(6.6 \mathrm{~mL}, 60.1 \mathrm{mmol})$ in xylene $(10 \mathrm{~mL})$ was added drop by drop by the top of the condenser. The mixture is heated for $24 \mathrm{~h}$. Then a new addition of a solution of phenylacetylene $(3.0 \mathrm{~mL}, 27.4 \mathrm{mmol})$ in xylene $(5 \mathrm{~mL})$ is done and reflux is extended for $24 \mathrm{~h}$. All the volatiles were removed under vacuum. Extraction of phosphazene $\mathbf{4 b}$ with pentane $(3 \times 20 \mathrm{~mL})$ is performed. Evaporation of solvent to obtain a saturated solution of pentane is realized and precipitation occurs at $-30{ }^{\circ} \mathrm{C}$. Phosphazene $\mathbf{4 b}$ is obtained as a brownish powder (12.4 g, $57 \%$ yield). M.p. $=105-107^{\circ} \mathrm{C} ;{ }^{31} \mathrm{P}\left\{{ }^{1} \mathrm{H}\right\} \mathrm{NMR}(121.5 \mathrm{MHz}, 298 \mathrm{~K}$, $\left.\mathrm{CDCl}_{3}\right): \delta=72.6 ;{ }^{1} \mathrm{H} \mathrm{NMR}\left(300.1 \mathrm{MHz}, 298 \mathrm{~K}, \mathrm{CDCl}_{3}\right): \delta=1.28\left(\mathrm{~d},{ }^{3} \mathrm{~J}_{\mathrm{HH}}=6.6 \mathrm{~Hz}\right.$, $\left.12 \mathrm{H}, \mathrm{NCHCH}_{3}\right), 1.34\left(\mathrm{~d},{ }^{3} \mathrm{JHH}_{\mathrm{HH}}=6.9 \mathrm{~Hz}, 12 \mathrm{H}, \mathrm{NCHCH}_{3}\right), 3.08\left(\mathrm{~d},{ }^{2} \mathrm{~J}_{\mathrm{HP}}=10.5 \mathrm{~Hz}\right.$, $2 \mathrm{H}, \mathrm{PCH}$ ), 3.73 (sept. d, ${ }^{3} \mathrm{~J}_{\mathrm{HH}}=6.9 \mathrm{~Hz},{ }^{3} \mathrm{JPP}_{\mathrm{HP}}=13.8 \mathrm{~Hz}, 4 \mathrm{H}, \mathrm{NCHCH}$ ), 6.82-6.83 ( $\left.\mathrm{m}, 3 \mathrm{H}, \mathrm{C} H_{\mathrm{Ar}}\right), 6.99-7.01\left(\mathrm{~m}, 2 \mathrm{H}, \mathrm{CH}_{\mathrm{Ar}}\right), 7.20-7.25\left(\mathrm{~m}, 3 \mathrm{H}, \mathrm{CH}_{\mathrm{Ar}}\right), 7.37-7.41(\mathrm{~m}$, $\left.2 \mathrm{H}, \mathrm{CH}_{\text {Ar }}\right) ;{ }^{13} \mathrm{C}\left\{{ }^{1} \mathrm{H}\right\} \mathrm{NMR}\left(75.1 \mathrm{MHz}, 298 \mathrm{~K}, \mathrm{CDCl}_{3}\right): \delta=23.1\left(\mathrm{~s}, \mathrm{NCHCH}_{3}\right), 23.3$ (s, $\left.\mathrm{NCHCH}_{3}\right), 36.4\left(\mathrm{~d},{ }^{1} \mathrm{~J} \mathrm{CP}=69.5 \mathrm{~Hz}, \mathrm{PCH}_{2}\right), 46.2\left(\mathrm{~s}, \mathrm{NCHCH}_{3}\right), 103.4\left(\mathrm{~d},{ }^{2} \mathrm{~J}_{\mathrm{CP}}=\right.$ $22.3 \mathrm{~Hz}, \mathrm{NC}=\mathrm{C}$ ), $121.8\left(\mathrm{~s}, \mathrm{CH}_{\mathrm{Ar}}\right), 126.0\left(\mathrm{~s}, \mathrm{CH}_{\mathrm{Ar}}\right), 126.7$ (s, $\left.\mathrm{CH}_{\mathrm{Ar}}\right), 127.5\left(\mathrm{~s}, \mathrm{CH}_{\mathrm{Ar}}\right)$, 128.4 (s, $\mathrm{CH}_{\mathrm{Ar}}$ ), 128.5 (s, $\mathrm{CH}_{\mathrm{Ar}}$ ), 140.3 (d, $\left.{ }^{3} \mathrm{~J}_{\mathrm{CP}}=16.3 \mathrm{~Hz}, \mathrm{C}_{\mathrm{ipso}}\right), 142.2$ (d, ${ }^{3} \mathrm{~J}_{\mathrm{CP}}=$ $\left.28.2 \mathrm{~Hz}, C_{\mathrm{ipso}}\right), 157.7$ (d, $\left.{ }^{2} \mathrm{~J}_{\mathrm{CP}}=12.1 \mathrm{~Hz}, \mathrm{~N}-\mathrm{C}=\mathrm{C}\right)$; HRMS $\left(\mathrm{DCl}-\mathrm{CH}_{4}\right): \mathrm{m} / \mathrm{z}$ calcd for $\mathrm{C}_{27} \mathrm{H}_{41} \mathrm{~N}_{3} \mathrm{P}: 438.3038[\mathrm{M}+\mathrm{H}]^{+}$; found: 438.3034.

Phosphonium salt $5 \mathbf{b}$ : A solution of $\mathrm{CBr}_{4}(6.98 \mathrm{~g}, 21.0 \mathrm{mmol})$ in dichloromethane $(20 \mathrm{~mL})$ was added dropwise at $-80{ }^{\circ} \mathrm{C}$ to a solution of cyclic phosphazene $4 \mathrm{~b}$ $(9.20 \mathrm{~g}, 21.0 \mathrm{mmol})$ in dichloromethane $(20 \mathrm{~mL})$. After stirring for $1 \mathrm{~h}$ at $-80{ }^{\circ} \mathrm{C}$, the solution was warmed up to room temperature. All the volatiles were removed under vacuum and the crude was washed with diethyl ether $(3 \times 10 \mathrm{~mL})$. Phosphonium salt $\mathbf{5 b}$ was obtained as a brownish powder $(8.2 \mathrm{~g}, 75 \%$ yield $)$. M.p. $=136-137{ }^{\circ} \mathrm{C} ;{ }^{31} \mathrm{P}\left\{{ }^{1} \mathrm{H}\right\} \mathrm{NMR}\left(121.5 \mathrm{MHz}, 298 \mathrm{~K}, \mathrm{CDCl}_{3}\right): \delta=66.3 ;{ }^{1} \mathrm{H} \mathrm{NMR}$ $\left(300.1 \mathrm{MHz}, 298 \mathrm{~K}, \mathrm{CDCl}_{3}\right): \delta=1.36\left(\mathrm{~d},{ }^{3} \mathrm{JHH}=6.6 \mathrm{~Hz}, 12 \mathrm{H}, \mathrm{NCHCH}_{3}\right), 1.38(\mathrm{~d}$, $\left.{ }^{3} \mathrm{JHH}_{\mathrm{HH}}=6.6 \mathrm{~Hz}, 12 \mathrm{H}, \mathrm{NCHCH} \mathrm{H}_{3}\right), 4.01$ (sept d, ${ }^{3} \mathrm{JHH}_{\mathrm{HH}}=6.3 \mathrm{~Hz},{ }^{3} \mathrm{JP}_{\mathrm{HP}}=12.9 \mathrm{~Hz}, 4 \mathrm{H}$, $\left.\mathrm{NCHCH}_{3}\right), 7.29-7.32\left(\mathrm{~m}, 3 \mathrm{H}, \mathrm{CH}_{\text {Ar }}\right), 7.38-7.42\left(\mathrm{~m}, 3 \mathrm{H}, \mathrm{CH}_{\text {Ar }}\right), 7.50-7.54(\mathrm{~m}, 2 \mathrm{H}$, $\left.\mathrm{CH}_{\text {Ar }}\right), 7.68-7.70\left(\mathrm{~m}, 2 \mathrm{H}, \mathrm{CH} H_{\text {Ar }}\right), 8.83\left(\mathrm{~d},{ }^{2} J_{\mathrm{HP}}=30.6 \mathrm{~Hz}, \mathrm{PCH}\right) ;{ }^{13} \mathrm{C}\left\{{ }^{1} \mathrm{H}\right\} \mathrm{NMR}(75.1$ $\left.\mathrm{MHz}, 298 \mathrm{~K}, \mathrm{CDCl}_{3}\right): \delta=22.5\left(\mathrm{~s}, \mathrm{NCHCH}_{3}\right), 22.8\left(\mathrm{~s}, \mathrm{NCHCH}_{3}\right), 48.5\left(\mathrm{~d},{ }^{2} \mathrm{~J}_{\mathrm{CP}}=3.9\right.$ $\mathrm{Hz}, \mathrm{NCHCH}$ ), 128.6 (s, $\left.\mathrm{CH}_{\mathrm{Ar}}\right), 128.7$ (s, $\left.\mathrm{CH}_{\mathrm{Ar}}\right), 128.9$ (s, $\left.\mathrm{CH}_{\mathrm{Ar}}\right), 130.8$ (s, $\mathrm{CH}_{\mathrm{Ar}}$ ), $132.4\left(\mathrm{~d},{ }^{3} \mathrm{~J}_{\mathrm{CP}}=23.6 \mathrm{~Hz}, C_{\mathrm{ipso}}\right), 133.3\left(\mathrm{~d},{ }^{3} \mathrm{~J}_{\mathrm{CP}}=28.9 \mathrm{~Hz}, C_{\mathrm{ipso}}\right), 134.1\left(\mathrm{~s}, \mathrm{CH}_{\mathrm{Ar}}\right)$, $134.7\left(\mathrm{~d},{ }^{1} \mathrm{~J}_{\mathrm{CP}}=101.8 \mathrm{~Hz}, \mathrm{PCH}\right), 156.8\left(\mathrm{~d},{ }^{2} \mathrm{~J}_{\mathrm{CP}}=34.3 \mathrm{~Hz}, \mathrm{NC}-\mathrm{C}\right), 183.5$ (d, ${ }^{2} \mathrm{~J}_{\mathrm{CP}}$ $=7.1 \mathrm{~Hz}, \mathrm{~N}=C)$; HRMS $\left(\mathrm{DCl}-\mathrm{CH}_{4}\right) \mathrm{m} / \mathrm{z}$ calcd for $\mathrm{C}_{27} \mathrm{H}_{39} \mathrm{~N}_{3} \mathrm{P}: 436.2882[\mathrm{M}]^{+}$; found: 436.2897

Phosphonium salt 5'b: Trimethylsilyltriflate $(5.1 \mathrm{~mL}, 28.0 \mathrm{mmol})$ was added drop by drop at $-80^{\circ} \mathrm{C}$ to a solution of phosphonium salt $5 \mathbf{b}(13.11 \mathrm{~g}, 25.4 \mathrm{mmol})$ in dichloromethane $(60 \mathrm{~mL})$. After $30 \mathrm{~min}$, the solution was warmed up to room temperature and the volatiles removed under vacuum. The crude was washed with diethyl ether $(3 \times 20 \mathrm{~mL})$. Then phosphonium salt $5^{\prime} \mathbf{b}$ was obtained as colorless crystals from a saturated $\mathrm{CH}_{2} \mathrm{Cl}_{2}-\mathrm{THF}$ solution $(7.9 \mathrm{~g}, 53 \%$ yield). M.p. $=137-138{ }^{\circ} \mathrm{C} ;{ }^{31} \mathrm{P}\left\{{ }^{1} \mathrm{H}\right\} \operatorname{NMR}\left(121.5 \mathrm{MHz}, 298 \mathrm{~K}, \mathrm{CDCl}_{3}\right): \delta=66.1 ;{ }^{29} \mathrm{Si} \mathrm{NMR}(59.0$ $\left.\mathrm{MHz}, 298 \mathrm{~K}, \mathrm{CDCl}_{3}\right): \delta=28.1 ;{ }^{19} \mathrm{~F} \mathrm{NMR}\left(282.4 \mathrm{MHz}, 298 \mathrm{~K}, \mathrm{CDCl}_{3}\right): \delta=-77.4 ;{ }^{1} \mathrm{H}$ $\operatorname{NMR}\left(300.1 \mathrm{MHz}, 298 \mathrm{~K}, \mathrm{CDCl}_{3}\right): \delta=1.29\left(\mathrm{~d},{ }^{3} \mathrm{JHH}_{\mathrm{HH}}=6.6 \mathrm{~Hz}, 12 \mathrm{H}, \mathrm{NCHCH}_{3}\right), 1.34$ (d, $\left.{ }^{3} \mathrm{JHH}_{\mathrm{HH}}=6.6 \mathrm{~Hz}, 12 \mathrm{H}, \mathrm{NCHCH}_{3}\right), 3.92\left(\mathrm{sept},{ }^{3} \mathrm{~J}_{\mathrm{HH}}=6.6 \mathrm{~Hz}, 4 \mathrm{H}, \mathrm{NCHCH}_{3}\right), 7.20$ $\left(\mathrm{m}, 2 \mathrm{H}, \mathrm{C} H_{\text {Ar }}\right), 7.37\left(\mathrm{~m}, 1 \mathrm{H}, \mathrm{CH}_{\text {Ar }}\right), 7.39\left(\mathrm{~m}, 2 \mathrm{H}, \mathrm{C} H_{\text {Ar }}\right), 7.43\left(\mathrm{~m}, 2 \mathrm{H}, \mathrm{CH} H_{\text {Ar }}\right), 7.50$ $\left(\mathrm{m}, 1 \mathrm{H}, \mathrm{CH}_{\mathrm{Ar}}\right), 7.61\left(\mathrm{~m}, 2 \mathrm{H}, \mathrm{CH}_{\mathrm{Ar}}\right), 7.93\left(\mathrm{~d},{ }^{2} \mathrm{JHP}_{\mathrm{HP}}=30.9 \mathrm{~Hz}, \mathrm{PCH}\right) ;{ }^{13} \mathrm{C}\left\{{ }^{1} \mathrm{H}\right\} \mathrm{NMR}$ $\left(75.1 \mathrm{MHz}, 298 \mathrm{~K}, \mathrm{CDCl}_{3}\right): \delta=22.2\left(\mathrm{~d},{ }^{3} \mathrm{~J}_{\mathrm{CP}}=1.4 \mathrm{~Hz}, \mathrm{NCHCH}_{3}\right), 22.3\left(\mathrm{~d},{ }^{3} J_{\mathrm{CP}}=\right.$ $\left.1.2 \mathrm{~Hz}, \mathrm{NCHCH}_{3}\right), 48.3\left(\mathrm{~d},{ }^{2} \mathrm{~J}_{\mathrm{CP}}=4.8 \mathrm{~Hz}, \mathrm{NCHCH}_{3}\right), 120.9$ (q, ${ }^{1} J_{\mathrm{CF}}=318.8 \mathrm{~Hz}$, $\left.\mathrm{CF}_{3}\right), 128.3$ (s, $\left.\mathrm{CH}_{\mathrm{Ar}}\right), 128.6$ (s, $\left.\mathrm{CH}_{\mathrm{Ar}}\right), 128.8$ (s, $\left.\mathrm{CH}_{\mathrm{Ar}}\right), 130.3\left(\mathrm{~s}, \mathrm{CH}_{\mathrm{Ar}}\right), 130.9$ (s, $\left.\mathrm{CH}_{\mathrm{Ar}}\right), 132.3\left(\mathrm{~d},{ }^{3} \mathrm{~J}_{\mathrm{CP}}=24.1 \mathrm{~Hz}, C_{\mathrm{ipso}}\right), 132.9\left(\mathrm{~d},{ }^{3} \mathrm{~J}_{\mathrm{CP}}=28.7 \mathrm{~Hz}, C_{\mathrm{ipso}}\right), 133.2(\mathrm{~d}$, $\left.{ }^{1} \mathrm{JCP}_{\mathrm{CP}} 102.7 \mathrm{~Hz}, \mathrm{PCH}\right), 134.2\left(\mathrm{~s}, \mathrm{CH}_{\mathrm{Ar}}\right), 157.2\left(\mathrm{~d},{ }^{2} \mathrm{~J}_{\mathrm{CP}}=33.4 \mathrm{~Hz}, \mathrm{NC}-\mathrm{C}\right), 183.2$ (d, $\left.{ }^{2} \mathrm{~J}_{\mathrm{CP}}=7.4 \mathrm{~Hz}, \mathrm{~N}=\mathrm{C}\right)$; HRMS $\left(\mathrm{DCl}-\mathrm{CH}_{4}\right): \mathrm{m} / \mathrm{z}$ calcd for $\mathrm{C}_{27} \mathrm{H}_{39} \mathrm{~N}_{3} \mathrm{P}: 436.2882$ $[\mathrm{M}]^{+}$; found : 436.2881

Azavinylidene phosphorane 6b: Phosphonium salt 5'b (100 mg, $0.17 \mathrm{mmol}$ ) and potassium hexamethyldisilazane $(35 \mathrm{mg}, 0.17 \mathrm{mmol})$ were dissolved in 0.6 $\mathrm{mL}$ of $\left[\mathrm{D}_{8}\right] \mathrm{THF}$ at $-80^{\circ} \mathrm{C}$. Cyclic azavinylidene phosphorane $6 \mathbf{b}$ was obtained and characterized by multinuclear NMR spectroscopy at $-80{ }^{\circ} \mathrm{C}$ without further purification. ${ }^{31} \mathrm{P}\left\{{ }^{1} \mathrm{H}\right\} \mathrm{NMR}\left(121.5 \mathrm{MHz}, 193 \mathrm{~K},\left[\mathrm{D}_{8}\right] \mathrm{THF}\right): \delta=95.8 ;{ }^{1} \mathrm{H}$ NMR $(300.1$ $\left.\mathrm{MHz}, 193 \mathrm{~K},\left[\mathrm{D}_{8}\right] \mathrm{THF}\right): \delta=1.42\left(\mathrm{~d},{ }^{3} \mathrm{JHH}_{\mathrm{HH}}=7.2 \mathrm{~Hz}, 12 \mathrm{H}, \mathrm{NCHCH}\right), 1.44\left(\mathrm{~d},{ }^{3} \mathrm{JHH}_{\mathrm{HH}}=\right.$ $\left.7.8 \mathrm{~Hz}, 12 \mathrm{H}, \mathrm{NCHCH}_{3}\right), 4.50(\mathrm{~m}, 4 \mathrm{H}, \mathrm{NCHCH}), 7.30\left(\mathrm{~m}, 3 \mathrm{H}, \mathrm{CH}_{\mathrm{Ar}}\right), 7.45(\mathrm{~m}, 2 \mathrm{H}$, $\left.\mathrm{CH}_{\text {Ar }}\right), 7.49\left(\mathrm{~m}, 2 \mathrm{H}, \mathrm{CH}_{\text {Ar }}\right), 7.61\left(\mathrm{~m}, 3 \mathrm{H}, \mathrm{CH}_{\text {Ar }}\right) ;{ }^{13} \mathrm{C}\left\{{ }^{1} \mathrm{H}\right\} \mathrm{NMR}(75.1 \mathrm{MHz}, 193 \mathrm{~K}$, $\left.\left[\mathrm{D}_{8}\right] \mathrm{THF}\right): \delta=23.2$ (s, $\mathrm{NCHCH}$ ), 42.4 (s, $\left.\mathrm{NCHCH}_{3}\right), 123.9$ (s, $\left.\mathrm{CH}_{\mathrm{Ar}}\right), 125.0$ (s, $\left.\mathrm{CH}_{\mathrm{Ar}}\right), 125.8\left(\mathrm{~s}, \mathrm{CH}_{\mathrm{Ar}}\right), 126.8\left(\mathrm{~s}, \mathrm{CH}_{\mathrm{Ar}}\right), 127.8\left(\mathrm{~s}, \mathrm{CH}_{\mathrm{Ar}}\right), 128.7\left(\mathrm{~s}, \mathrm{CH}_{\mathrm{Ar}}\right), 135.5(\mathrm{~d}$, $\left.{ }^{3} J_{\mathrm{CP}}=40.4 \mathrm{~Hz}, C_{\mathrm{ipso}}\right), 142.1\left(\mathrm{~d},{ }^{3} \mathrm{~J}_{\mathrm{CP}}=56.7 \mathrm{~Hz}, C_{\mathrm{ipso}}\right), 156.6\left(\mathrm{~d},{ }^{2} \mathrm{~J}_{\mathrm{CP}}=9.2 \mathrm{~Hz}\right.$, $\mathrm{NC}=C), 175.9\left(\mathrm{~d},{ }^{2} \mathrm{~J}_{\mathrm{CP}}=42.1 \mathrm{~Hz}, \mathrm{~N}-\mathrm{C}\right), 234.4\left(\mathrm{~d},{ }^{1} \mathrm{~J}_{\mathrm{CP}}=93.6 \mathrm{~Hz}, \mathrm{PC}\right)$.

Azaphosphetane 7: Phosphonium salt 5'b $(60 \mathrm{mg}, 0,10 \mathrm{mmol})$ and potassium hexamethyldisilazane $(20 \mathrm{mg}, 0,10 \mathrm{mmol})$ were dissolved in $0.6 \mathrm{~mL}$ of $\left[\mathrm{D}_{8}\right] \mathrm{THF}$ at $-80{ }^{\circ} \mathrm{C}$. The solution was slowly warmed up to room temperature. Azaphosphetane 7 was obtained quantitatively (indicated by ${ }^{31} \mathrm{P}$ NMR) and analyzed without further purification (43.5 mg). ${ }^{31} \mathrm{P}\left\{{ }^{1} \mathrm{H}\right\} \mathrm{NMR}(121.5 \mathrm{MHz}, 298 \mathrm{~K}$, $\left.\mathrm{C}_{6} \mathrm{D}_{6}\right): \delta=66.6$. ${ }^{1} \mathrm{H}$ NMR $\left(300.1 \mathrm{MHz}, 298 \mathrm{~K}, \mathrm{C}_{6} \mathrm{D}_{6}\right): \delta=0.88\left(\mathrm{~d},{ }^{3} \mathrm{~J}_{\mathrm{HH}}=6.3 \mathrm{~Hz}\right.$, $\left.3 \mathrm{H}, \mathrm{NCHCH}_{3}\right), 1.14\left(\mathrm{~d},{ }^{3} \mathrm{JHH}_{\mathrm{HH}}=6.8 \mathrm{~Hz}, 6 \mathrm{H}, \mathrm{NCHCH}_{3}\right), 1.26\left(\mathrm{~d},{ }^{3} \mathrm{JHH}_{\mathrm{HH}}=6.3 \mathrm{~Hz}, 6 \mathrm{H}\right.$, $\mathrm{NCHCH}_{3}$ ), $1.28\left(\mathrm{~d},{ }^{3} \mathrm{JHH}_{\mathrm{HH}}=6.6 \mathrm{~Hz}, 3 \mathrm{H}, \mathrm{NCHCH}_{3}\right), 1.33$ (s, 3H, $\left.\mathrm{NCCH}_{3}\right), 1.44$ (s, $\left.3 \mathrm{H}, \mathrm{NCCH}_{3}\right), 3.18\left(\mathrm{sept},{ }^{3} \mathrm{JHH}_{\mathrm{HH}}=6.8 \mathrm{~Hz},{ }^{3} \mathrm{JPH}_{\mathrm{PH}}=7.8 \mathrm{~Hz}, 1 \mathrm{H}, \mathrm{NCHCH}_{3}\right), 3.37\left(\mathrm{~d},{ }^{2} \mathrm{~J}_{\mathrm{HP}}\right.$ $=12.0 \mathrm{~Hz}, 1 \mathrm{H}, \mathrm{PCH}), 3.63(\mathrm{~m}, 2 \mathrm{H}, \mathrm{NCHCH}), 6.81-6.87\left(\mathrm{~m}, 2 \mathrm{H}, \mathrm{CH}_{\mathrm{Ar}}\right), 7.04-7.08$ $\left(\mathrm{m}, 3 \mathrm{H}, \mathrm{CH}_{\mathrm{Ar}}\right), 7.09-7.11\left(\mathrm{~m}, 2 \mathrm{H}, \mathrm{CH}_{\mathrm{Ar}}\right), 7.18-7.20\left(\mathrm{~m}, 2 \mathrm{H}, \mathrm{CH}_{\mathrm{Ar}}\right), 7.91-7.94(\mathrm{~m}$, $\left.1 \mathrm{H}, \mathrm{CH}_{\mathrm{Ar}}\right) .{ }^{13} \mathrm{C}\left\{{ }^{1} \mathrm{H}\right\} \operatorname{NMR}\left(75.1 \mathrm{MHz}, 298 \mathrm{~K}, \mathrm{C}_{6} \mathrm{D}_{6}\right): \delta=21.3\left(\mathrm{~d},{ }^{3} \mathrm{~J}_{\mathrm{CP}}=5.6 \mathrm{~Hz}\right.$, $\mathrm{NCCH}_{3}$ ), 22.4 (s large, $\mathrm{NCHCH}_{3}$ ), 22.9 (s large, $\mathrm{NCHCH}_{3}$ ), 23.4 (d, ${ }^{3} \mathrm{~J}_{\mathrm{CP}}=6.6 \mathrm{~Hz}$, $\mathrm{NCHCH}_{3}$ ), 24.1 (d, $\left.{ }^{3} J_{\mathrm{CP}}=6.1 \mathrm{~Hz}, \mathrm{NCHCH}_{3}\right), 32.4\left(\mathrm{~d},{ }^{3} \mathrm{~J}_{\mathrm{CP}}=10.3 \mathrm{~Hz}, \mathrm{NCCH}_{3}\right.$ ), $44.7\left(\mathrm{~d},{ }^{2} \mathrm{~J}_{\mathrm{CP}}=3.8 \mathrm{~Hz}, \mathrm{NCHCH}_{3}\right), 47.4\left(\mathrm{~d},{ }^{2} \mathrm{~J}_{\mathrm{CP}}=4.9 \mathrm{~Hz}, \mathrm{NCHCH}_{3}\right), 61.9\left(\mathrm{~d},{ }^{1} \mathrm{~J}_{\mathrm{CP}}\right.$ $=54.7 \mathrm{~Hz}, \mathrm{PCH}), 66.7\left(\mathrm{~d},{ }^{2} \mathrm{~J}_{\mathrm{CP}}=6.7 \mathrm{~Hz}, \mathrm{NC}\left(\mathrm{CH}_{3}\right)_{2}\right), 110.8\left(\mathrm{~d},{ }^{2} \mathrm{~J}_{\mathrm{CP}}=17.3 \mathrm{~Hz}, \mathrm{~N}-\right.$ $\mathrm{C}=C), 122.5\left(\mathrm{~s}, \mathrm{CH}_{\mathrm{Ar}}\right), 127.4\left(\mathrm{~s}, \mathrm{CH}_{\mathrm{Ar}}\right), 127.6\left(\mathrm{~s}, \mathrm{CH}_{\mathrm{Ar}}\right), 127.9\left(\mathrm{~s}, \mathrm{CH}_{\mathrm{Ar}}\right), 128.2(\mathrm{~s}$, $\mathrm{CH}_{\mathrm{Ar}}$ ), 129.6 (s, $\left.\mathrm{CH}_{\mathrm{Ar}}\right), 141.3$ (d, $\left.{ }^{3} \mathrm{~J}_{\mathrm{CP}}=15.6 \mathrm{~Hz}, C_{\mathrm{ipso}}\right), 142.4\left(\mathrm{~d},{ }^{3} \mathrm{~J}_{\mathrm{CP}}=30.1 \mathrm{~Hz}\right.$, Cipso), 162.7 (d, $\left.{ }^{2} J_{\mathrm{CP}}=17.2 \mathrm{~Hz}, \mathrm{~N}-\mathrm{C}\right)$.

Spiro phosphazene 8: Phosphonium salt 5'b (60 mg, $0.10 \mathrm{mmol})$ and potassium hexamethyldisilazane $(20 \mathrm{mg}, 0,10 \mathrm{mmol})$ were dissolved in $0.7 \mathrm{~mL}$ of $\left[\mathrm{D}_{8}\right] \mathrm{THF}$ at $-80^{\circ} \mathrm{C}$. After $30 \mathrm{~min}$, methylacrylate $(18.9 \mu \mathrm{L}, 0.21 \mathrm{mmol})$ was added and the solution was kept at $-60^{\circ} \mathrm{C}$ for $48 \mathrm{~h}$. Spiro derivative 8 was obtained quantitatively as indicated by ${ }^{31} \mathrm{P}$ NMR. This product is not stable at room temperature and was analyzed by multinuclear NMR at $-40{ }^{\circ} \mathrm{C} .{ }^{31} \mathrm{P}\left\{{ }^{1} \mathrm{H}\right\} \mathrm{NMR}(161.9 \mathrm{MHz}, 233 \mathrm{~K}$, $\left.\left[\mathrm{D}_{8}\right] \mathrm{THF}\right): \delta=75.7 ;{ }^{1} \mathrm{H}$ NMR $\left(400.1 \mathrm{MHz}, 233 \mathrm{~K},\left[\mathrm{D}_{8}\right] \mathrm{THF}\right): \delta=1.32(\mathrm{~m}, 6 \mathrm{H}$, $\left.\mathrm{NCHCH}_{3}\right), 1.41\left(\mathrm{~d},{ }^{3} \mathrm{JHH}_{\mathrm{HH}}=6.8 \mathrm{~Hz}, 12 \mathrm{H}, \mathrm{NCHCH}_{3}\right), 1.42\left(\mathrm{~m}, 1 \mathrm{H}, \mathrm{CH}_{\text {2cycle }}\right), 1.48(\mathrm{~m}$, $6 \mathrm{H}, \mathrm{NCHCH}_{3}$ ), 1.89 (ddd, ${ }^{2} \mathrm{~J}_{\mathrm{HH}}=4.0 \mathrm{~Hz},{ }^{3} \mathrm{~J}_{\mathrm{HH}}=6.4 \mathrm{~Hz},{ }^{3} \mathrm{JHP}_{\mathrm{HP}}=13.0 \mathrm{~Hz}, 1 \mathrm{H}, \mathrm{CH}_{2 \mathrm{cycle}}$ ), 2.10 (ddd, $\left.{ }^{3} \mathrm{JHH}_{\mathrm{HH}}=5.6 \mathrm{~Hz},{ }^{3} \mathrm{JHH}_{\mathrm{HH}}=6.4 \mathrm{~Hz},{ }^{3} \mathrm{JHP}_{\mathrm{HP}}=7.6 \mathrm{~Hz}, 1 \mathrm{H}, \mathrm{CH}_{\text {cycle }}\right), 3.66(\mathrm{~m}, 1 \mathrm{H}$, $\mathrm{NCHCH}_{3}$ ), 3.69 (s, 3H, OCH$\left.H_{3}\right), 3.99\left(\mathrm{~m}, 1 \mathrm{H}, \mathrm{NCHCH}_{3}\right), 4.09(\mathrm{~m}, 2 \mathrm{H}, \mathrm{NCHCH}$ ), 7.00-7.01 (m, 3H, CH $\left.H_{\text {Ar }}\right), 7.01-7.02\left(\mathrm{~m}, 2 \mathrm{H}, \mathrm{CH}_{\text {Ar }}\right), 7.20-7.21\left(\mathrm{~m}, 1 \mathrm{H}, \mathrm{CH}_{\text {Ar }}\right), 7.26-$ $7.28\left(\mathrm{~m}, 2 \mathrm{H}, \mathrm{CH}_{\mathrm{Ar}}\right), 7.39-7.41\left(\mathrm{~m}, 2 \mathrm{H}, \mathrm{C} \mathrm{H}_{\mathrm{Ar}}\right) ;{ }^{13} \mathrm{C}\left\{{ }^{1} \mathrm{H}\right\} \mathrm{NMR}(100.1 \mathrm{MHz}, 233 \mathrm{~K}$, [D8]THF): $\delta=21.3\left(\mathrm{~s}, \mathrm{NCHCH}_{3}\right), 22.3\left(\mathrm{~d},{ }^{2} \mathrm{~J}_{\mathrm{CP}}=2.8 \mathrm{~Hz}, \mathrm{CH}_{2 \mathrm{cycle}}\right.$ ), 22.5 (s, $\mathrm{NCHCH}_{3}$ ), 25.1 (d, $\left.{ }^{3} \mathrm{JCP}_{\mathrm{CP}}=3.2 \mathrm{~Hz}, \mathrm{NCHCH}_{3}\right), 26.6$ (d, ${ }^{2} \mathrm{~J} \mathrm{CP}=7.2 \mathrm{~Hz}, \mathrm{CH}_{\text {cycle }}$ ), 37.3 (d, ${ }^{1} \mathrm{~J}_{\mathrm{CP}}=96.7 \mathrm{~Hz}, \mathrm{PC}$ ), 47.1 (s, $\left.\mathrm{NCHCH}_{3}\right), 47.6$ (s, $\left.\mathrm{NCHCH}_{3}\right), 47.9$ (s, $\mathrm{NCHCH}_{3}$ ), $51.7\left(\mathrm{~s}, \mathrm{OCH}_{3}\right), 109.6\left(\mathrm{~d},{ }^{2} \mathrm{~J}_{\mathrm{CP}}=36.6 \mathrm{~Hz}, \mathrm{NC}=\mathrm{C}\right), 125.8\left(\mathrm{~s}, \mathrm{CH}_{\mathrm{Ar}}\right), 126.6\left(\mathrm{~s}, \mathrm{CH}_{\mathrm{Ar}}\right)$, $128.3\left(\mathrm{~s}, \mathrm{CH}_{\mathrm{Ar}}\right), 128.9\left(\mathrm{~s}, \mathrm{CH}_{\mathrm{Ar}}\right), 138.3\left(\mathrm{~d},{ }^{3} \mathrm{~J}_{\mathrm{CP}}=12.8 \mathrm{~Hz}, C_{\mathrm{ipso}}\right), 139.9\left(\mathrm{~d},{ }^{3} \mathrm{~J}_{\mathrm{CP}}=\right.$ $\left.24.6 \mathrm{~Hz}, C_{\text {ipso }}\right), 151.9\left(\mathrm{~d},{ }^{2} \mathrm{~J}_{\mathrm{CP}}=8.1 \mathrm{~Hz}, \mathrm{~N}-\mathrm{C}\right), 172.4\left(\mathrm{~d},{ }^{3} \mathrm{~J}_{\mathrm{CP}}=5.3 \mathrm{~Hz}, C=\mathrm{O}\right)$.

Spiro phosphonium salt 9: Phosphonium salt 5'b (182 $\mathrm{mg}, 0,31 \mathrm{mmol}$ ) and potassium hexamethyldisilazane $(61.7 \mathrm{mg}, 0,31 \mathrm{mmol})$ were dissolved in $3.0 \mathrm{~mL}$ of THF at $-80^{\circ} \mathrm{C}$. After $30 \mathrm{~min}$, methylacrylate $(56 \mu \mathrm{L}, 0.62 \mathrm{mmol})$ was added and the solution was kept at $-60^{\circ} \mathrm{C}$ for $48 \mathrm{~h}$. One equivalent of methyltriflate (35 $\mu \mathrm{L}, 0,31 \mathrm{mmol}$ ) was added $-60{ }^{\circ} \mathrm{C}$ then the solution was warmed up to room temperature. All volatiles were removed under vacuum, and the crude was washed with diethyl ether $(3 \times 2 \mathrm{~mL})$. Spiro phosphonium salt 9 was obtained as 
a white powder (95.6 mg, $45 \%$ yield). M.p. $=142-144{ }^{\circ} \mathrm{C} ;{ }^{31} \mathrm{P}\left\{{ }^{1} \mathrm{H}\right\} \operatorname{NMR}(121.5$ $\left.\mathrm{MHz}, 298 \mathrm{~K}, \mathrm{CDCl}_{3}\right): \delta=72.7 ;{ }^{1} \mathrm{H}$ NMR $\left(300.1 \mathrm{MHz}, 298 \mathrm{~K}, \mathrm{CDCl}_{3}\right): \delta=1.45(\mathrm{~d}$ $\left.{ }^{3} \mathrm{JHH}_{\mathrm{HH}}=6.9 \mathrm{~Hz}, 6 \mathrm{H}, \mathrm{NCHCH}_{3}\right), 1.48\left(\mathrm{~d},{ }^{3} \mathrm{~J}_{\mathrm{HH}}=6.9 \mathrm{~Hz}, 6 \mathrm{H}, \mathrm{NCHCH}_{3}\right), 1.49\left(\mathrm{~d},{ }^{3} \mathrm{JHH}_{\mathrm{H}}\right.$ $\left.=6.6 \mathrm{~Hz}, 6 \mathrm{H}, \mathrm{NCHCH}_{3}\right), 1.50\left(\mathrm{~d},{ }^{3} \mathrm{~J}_{\mathrm{HH}}=6.6 \mathrm{~Hz}, 6 \mathrm{H}, \mathrm{NCHCH}_{3}\right), 1.52(\mathrm{~m}, 1 \mathrm{H}$, $\mathrm{CH}_{2 \text { cycle), }} 2.11$ (ddd, ${ }^{2} \mathrm{JHH}_{\mathrm{HH}}=4.5 \mathrm{~Hz},{ }^{3} \mathrm{JHH}_{\mathrm{HH}}=6.6 \mathrm{~Hz},{ }^{3} \mathrm{JPP}=16.5 \mathrm{~Hz}, 1 \mathrm{H}, \mathrm{CH}_{2 \mathrm{cycle}}$ ), 2.49 (ddd, ${ }^{3} \mathrm{JHH}_{\mathrm{HH}}=6.6 \mathrm{~Hz},{ }^{3} \mathrm{JHH}_{\mathrm{HH}}=9.0 \mathrm{~Hz},{ }^{3} \mathrm{JHP}_{\mathrm{HP}}=16.5 \mathrm{~Hz}, 1 \mathrm{H}, \mathrm{CH}$ cycle), 2.75 (d, ${ }^{3} \mathrm{JHP}_{\mathrm{HP}}$ $\left.=10.5 \mathrm{~Hz}, 3 \mathrm{H}, \mathrm{NCH}_{3}\right), 3.79\left(\mathrm{~s}, 3 \mathrm{H}, \mathrm{OCH}_{3}\right), 3.95$ (sept d, ${ }^{3} \mathrm{JHH}_{\mathrm{HH}}=6.6 \mathrm{~Hz},{ }^{2} \mathrm{JHP}_{\mathrm{HP}}=13.2$ $\mathrm{Hz}, 2 \mathrm{H}, \mathrm{NCHCH}_{3}$ ), 4.03 (sept d, ${ }^{3} \mathrm{~J}_{\mathrm{HH}}=7.2 \mathrm{~Hz},{ }^{2} \mathrm{JHP}_{\mathrm{HP}}=14.4 \mathrm{~Hz}, 2 \mathrm{H}, \mathrm{NCHCH}_{3}$ ), 6.80-6.89 (m, 2H, CHAr $), 6.94-7.05\left(\mathrm{~m}, 2 \mathrm{H}, \mathrm{CH}_{\text {Ar }}\right), 7.19-7.21\left(\mathrm{~m}, 3 \mathrm{H}, \mathrm{CH}_{\text {Ar }}\right), 7.21$ $7.22\left(\mathrm{~m}, 3 \mathrm{H}, \mathrm{C} H_{\mathrm{Ar}}\right) ;{ }^{13} \mathrm{C}\left\{{ }^{1} \mathrm{H}\right\} \mathrm{NMR}\left(75.1 \mathrm{MHz}, 298 \mathrm{~K}, \mathrm{CDCl}_{3}\right): \delta=22.1\left(\mathrm{~d},{ }^{3} \mathrm{~J}_{\mathrm{CP}}=\right.$ $0.8 \mathrm{~Hz}, \mathrm{NCHCH}_{3}$ ), 23.7 (s, $\mathrm{NCHCH}_{3}$ ), 23.8 (s, $\mathrm{NCHCH}_{3}$ ), 23.9 (s, $\mathrm{CH}_{2 \mathrm{cycle}}$ ), 25.2 (d, $\left.{ }^{3} \mathrm{~J}_{\mathrm{CP}}=2.2 \mathrm{~Hz}, \mathrm{NCHCH}_{3}\right), 29.4\left(\mathrm{~d},{ }^{3} \mathrm{~J}_{\mathrm{CP}}=5.7 \mathrm{~Hz}, \mathrm{CH}_{\mathrm{cycle}}\right.$ ), $30.6\left(\mathrm{~d},{ }^{1} \mathrm{~J}_{\mathrm{CP}}=134.4\right.$ $\mathrm{Hz}, \mathrm{PC}$ ), 34.9 (d, $\left.{ }^{2} \mathrm{~J}_{\mathrm{CP}}=1.0 \mathrm{~Hz}, \mathrm{NCH}_{3}\right), 49.9\left(\mathrm{~d},{ }^{2} \mathrm{~J}_{\mathrm{CP}}=4.8 \mathrm{~Hz}, \mathrm{NCHCH}_{3}\right), 50.0$ (d, $\left.{ }^{2} J_{\mathrm{CP}}=4.9 \mathrm{~Hz}, \mathrm{NCHCH}_{3}\right), 53.1\left(\mathrm{~s}, \mathrm{OCH}_{3}\right), 116.5\left(\mathrm{~d},{ }^{2} \mathrm{~J}_{\mathrm{CP}}=18,6 \mathrm{~Hz}, \mathrm{NC}=C\right), 126.4$ (s, $\left.\mathrm{CH}_{\mathrm{Ar}}\right), 126.6\left(\mathrm{~s}, \mathrm{CH}_{\mathrm{Ar}}\right), 126.7\left(\mathrm{~s}, \mathrm{CH}_{\mathrm{Ar}}\right), 129.2\left(\mathrm{~s}, \mathrm{CH}_{\mathrm{Ar}}\right), 129.6\left(\mathrm{~d},{ }^{3} \mathrm{~J}_{\mathrm{CP}}=8.1 \mathrm{~Hz}\right.$, $\left.C_{\text {ipso }}\right), 130.2\left(\mathrm{~d},{ }^{3} J_{\mathrm{CP}}=9.5 \mathrm{~Hz}, C_{\mathrm{ipso}}\right), 131.2\left(\mathrm{~s}, \mathrm{CH}_{\mathrm{Ar}}\right), 170.3\left(\mathrm{~d},{ }^{2} \mathrm{~J}_{\mathrm{CP}}=5.6 \mathrm{~Hz}, \mathrm{~N}-\right.$ C), $174.8(\mathrm{~s}, \mathrm{C}=\mathrm{O})$; HRMS (DCl-CH$) \mathrm{m} / \mathrm{z}$ calcd for $\mathrm{C}_{32} \mathrm{H}_{47} \mathrm{~N}_{3} \mathrm{O}_{2} \mathrm{P} 536.3406[\mathrm{M}]^{+}$; found: 536.3412

Rhodium cyclooctadiene complex 10: Phosphonium salt 5'b (100 mg, 0,17 $\mathrm{mmol}$ ) and potassium hexamethyldisilazane (35 $\mathrm{mg}, 0,18 \mathrm{mmol}$ ) were dissolved in $2 \mathrm{~mL}$ of $\mathrm{THF}$ at $-80^{\circ} \mathrm{C}$. After $30 \mathrm{~min}$, a solution of $[\mathrm{RhCl}(\mathrm{COD})]_{2}$ (42 $\mathrm{mg}, 0.085$ $\mathrm{mmol})$ in THF $(1 \mathrm{~mL})$ was added and stirred for $15 \mathrm{~h}$ at $-80^{\circ} \mathrm{C}$. Then the solution was warmed up to room temperature and the volatiles removed under vacuum. The crude was washed with diethyl ether $(2 \times 2 \mathrm{~mL})$ and complex 10 was extracted with dichloromethane. Red crystal of $\mathbf{1 0}$ were grown from a dichloromethane-diethyl ether solution at $-30^{\circ} \mathrm{C}(82 \mathrm{mg}, 71 \%$ yield $)$. M.p. $=159-$ $161{ }^{\circ} \mathrm{C} ;{ }^{31} \mathrm{P}\left\{{ }^{1} \mathrm{H}\right\}$ NMR $\left(121.5 \mathrm{MHz}, 298 \mathrm{~K},\left[\mathrm{D}_{8}\right] \mathrm{THF}\right): \delta=80.9\left(\mathrm{~d},{ }^{2} \mathrm{JPRh}=6.2 \mathrm{~Hz}\right)$ ${ }^{1} \mathrm{H}$ NMR $\left(300.1 \mathrm{MHz}, 298 \mathrm{~K},\left[\mathrm{D}_{8}\right] \mathrm{THF}\right): \delta=1.46\left(\mathrm{~d},{ }^{3} \mathrm{JHH}_{\mathrm{HH}}=4.2 \mathrm{~Hz}, 12 \mathrm{H}, \mathrm{NCHCH}_{3}\right)$ $1.50\left(\mathrm{~d},{ }^{3} \mathrm{JHH}_{\mathrm{HH}}=6.9 \mathrm{~Hz}, 12 \mathrm{H}, \mathrm{NCHCH}_{3}\right), 1.73\left(\mathrm{~s}, 4 \mathrm{H}, \mathrm{CH}_{2}\right), 2.18\left(\mathrm{~s}, 4 \mathrm{H}, \mathrm{CH}_{2}\right), 3.34$ (s, 2H, CH), $4.11\left(\mathrm{~s}, 4 \mathrm{H}, \mathrm{NCHCH}_{3}\right), 4.79(\mathrm{~s}, 2 \mathrm{H}, \mathrm{CH}), 7.23-7.46\left(\mathrm{~m}, 2 \mathrm{H}, \mathrm{CH}_{\mathrm{Ar}}\right)$, 7.27-7.28 (m, 2H, $\left.\mathrm{CH}_{\text {Ar }}\right), 7.29-7.30\left(\mathrm{~m}, 1 \mathrm{H}, \mathrm{CH}_{\mathrm{Ar}}\right), 7.39-7.42\left(\mathrm{~m}, 1 \mathrm{H}, \mathrm{CH}_{\mathrm{Ar}}\right), 7.43-$ $7.46\left(\mathrm{~m}, 2 \mathrm{H}, \mathrm{CH} \mathrm{Ar}_{\mathrm{Ar}}\right), 7.72-7.75\left(\mathrm{~m}, 2 \mathrm{H}, \mathrm{CH} \mathrm{Ar}_{\mathrm{Ar}}\right) ;{ }^{13} \mathrm{C}\left\{{ }^{1} \mathrm{H}\right\} \mathrm{NMR}(75.1 \mathrm{MHz}, 298 \mathrm{~K}$, [D8]THF): $\delta=23.8\left(\mathrm{~s}, \mathrm{NCHCH}_{3}\right), 23.9\left(\mathrm{~s}, \mathrm{NCHCH}_{3}\right), 28.6\left(\mathrm{~s}, \mathrm{CH}_{2}\right), 32.6\left(\mathrm{~s}, \mathrm{CH}_{2}\right)$, $48.9\left(\mathrm{~d},{ }^{2} \mathrm{~J}_{\mathrm{CP}}=4.9 \mathrm{~Hz}, \mathrm{NCHCH}_{3}\right), 66.7$ (s, $\left.\mathrm{CH}\right), 94.7$ (s, CH), 126.7 (s, $\mathrm{CH}_{\mathrm{Ar}}$ ), 126.9 (s, $\left.\mathrm{CH}_{\mathrm{Ar}}\right), 127.5$ (s, $\mathrm{CH}_{\mathrm{Ar}}$ ), 129.7 (s, $\left.\mathrm{CH}_{\mathrm{Ar}}\right), 130.4$ (s, $\left.\mathrm{CH}_{\mathrm{Ar}}\right), 131.1$ (s, $\mathrm{CH}_{\mathrm{Ar}}$ ), 136.4 (d, $\left.{ }^{3} \mathrm{~J}_{\mathrm{CP}}=32.3 \mathrm{~Hz}, C_{\mathrm{ipso}}\right), 141.4$ (d, $\left.{ }^{3} \mathrm{~J}_{\mathrm{CP}}=37.9 \mathrm{~Hz}, C_{\mathrm{ipso}}\right), 156.3$ (d, ${ }^{2} \mathrm{~J}_{\mathrm{CP}}=$ $30.9 \mathrm{~Hz}, \mathrm{~N}-\mathrm{C}$ ), 180.0 (dd, ${ }^{2} \mathrm{~J}_{\mathrm{CP}}=20.9 \mathrm{~Hz},{ }^{2} \mathrm{~J}_{\mathrm{CRh}}=3.4 \mathrm{~Hz}, \mathrm{NC}=C$ ), 195.8 (dd, ${ }^{1} \mathrm{~J}_{\mathrm{CP}}$ $\left.=41.2 \mathrm{~Hz},{ }^{1} \mathrm{~J}_{\mathrm{CRh}}=7.6 \mathrm{~Hz}, \mathrm{PC}\right) ; \mathrm{HRMS}\left(\mathrm{DCl}-\mathrm{CH}_{4}\right) \mathrm{m} / \mathrm{z}$ calcd for $\mathrm{C}_{35} \mathrm{H}_{50} \mathrm{~N}_{3} \mathrm{PCIRh}$ : $681.2486[\mathrm{M}+\mathrm{H}]^{+}$; found: 681.2469 .

Rhodium carbonyl complex 11: Carbon monoxide is bubbled into a solution of rhodium cyclooctadiene complex 10 (50 $\mathrm{mg}, 0.07 \mathrm{mmol}$ ) in dichloromethane (2 $\mathrm{mL}$ ) at room temperature. The solution turns from red to yellow, then all the volatiles were removed under vacuum. 11 is obtained as a yellow powder (46.1 $\mathrm{mg}, 90 \%$ yield); IR (THF): $\mathrm{v}=2066,1990 \mathrm{~cm}^{-1}(\mathrm{CO}) ; \mathrm{m} . \mathrm{p} .=130-132{ }^{\circ} \mathrm{C} ;{ }^{31} \mathrm{P}\left\{{ }^{1} \mathrm{H}\right\}$ NMR (121.5 MHz, $\left.298 \mathrm{~K},\left[\mathrm{D}_{8}\right] \mathrm{THF}\right): \delta=84.6\left(\mathrm{~d},{ }^{2} \mathrm{JPRh}=6.7 \mathrm{~Hz}\right) ;{ }^{1} \mathrm{H}$ NMR $(300.1$ $\left.\mathrm{MHz}, 298 \mathrm{~K},\left[\mathrm{D}_{8}\right] \mathrm{THF}\right): \delta=1.27\left(\mathrm{~d},{ }^{3} \mathrm{JHH}_{\mathrm{HH}}=6.6 \mathrm{~Hz}, 12 \mathrm{H}, \mathrm{NCHCH}\right), 1.38\left(\mathrm{~d},{ }^{3} \mathrm{JHH}_{\mathrm{HH}}=\right.$ $\left.6.6 \mathrm{~Hz}, 12 \mathrm{H}, \mathrm{NCHCH}_{3}\right), 4.22\left(\mathrm{sept},{ }^{3} \mathrm{JHH}_{\mathrm{HH}}=6.9 \mathrm{~Hz}, 4 \mathrm{H}, \mathrm{NCHCH}_{3}\right), 7.14-7.19(\mathrm{~m}$, $\left.3 \mathrm{H}, \mathrm{CH}_{\text {Ar }}\right), 7.21-7.24\left(\mathrm{~m}, 2 \mathrm{H}, \mathrm{CH}_{\text {Ar }}\right), 7.29-7.32\left(\mathrm{~m}, 2 \mathrm{H}, \mathrm{C} H_{\text {Ar }}\right), 7.38-7.40(\mathrm{~m}, 3 \mathrm{H}$, $\left.\mathrm{CH}_{\mathrm{Ar}}\right) ;{ }^{13} \mathrm{C}\left\{{ }^{1} \mathrm{H}\right\}$ NMR $\left(75.1 \mathrm{MHz}, 298 \mathrm{~K},\left[\mathrm{D}_{8}\right] \mathrm{THF}\right): \delta=23.6\left(\mathrm{~d},{ }^{3} \mathrm{~J}_{\mathrm{CP}}=1.7 \mathrm{~Hz}\right.$, $\left.\mathrm{NCHCH}_{3}\right), 23.8\left(\mathrm{~d},{ }^{3} \mathrm{~J} \mathrm{CP}=2.9 \mathrm{~Hz}, \mathrm{NCHCH}_{3}\right), 48.8\left(\mathrm{~d},{ }^{2} \mathrm{~J} \mathrm{CP}=4.9 \mathrm{~Hz}, \mathrm{NCHCH}_{3}\right)$, $127.2\left(\mathrm{~s}, \mathrm{CH}_{\mathrm{Ar}}\right), 127.9$ (s, $\left.\mathrm{CH}_{\mathrm{Ar}}\right), 128.2\left(\mathrm{~s}, \mathrm{CH}_{\mathrm{Ar}}\right), 129.9$ (s, $\left.\mathrm{CH}_{\mathrm{Ar}}\right), 130.4\left(\mathrm{~s}, \mathrm{CH}_{\mathrm{Ar}}\right.$ ), $131.9\left(\mathrm{~s}, \mathrm{CH}_{\mathrm{Ar}}\right), 135.2$ (d, $\left.{ }^{3} \mathrm{~J}_{\mathrm{CP}}=31.4 \mathrm{~Hz}, C_{\mathrm{ipso}}\right), 140.8$ (d, ${ }^{3} \mathrm{~J}_{\mathrm{CP}}=36.4 \mathrm{~Hz}, C_{\text {ipso }}$ ), $159.5\left(\mathrm{~d},{ }^{2} \mathrm{~J}_{\mathrm{CP}}=29.7 \mathrm{~Hz}, \mathrm{~N}-\mathrm{C}\right), 177.9\left(\mathrm{dd},{ }^{1} \mathrm{~J}_{\mathrm{CP}}=35.8 \mathrm{~Hz},{ }^{1} \mathrm{~J}_{\mathrm{CRh}}=23.6 \mathrm{~Hz}, \mathrm{PC}\right)$, $181.4\left(\mathrm{dd},{ }^{2} \mathrm{~J}_{\mathrm{CP}}=18.5 \mathrm{~Hz},{ }^{2} \mathrm{~J}_{\mathrm{CRh}}=2.9 \mathrm{~Hz}, \mathrm{~N}-\mathrm{C}=\mathrm{C}\right), 183.5\left(\mathrm{~d},{ }^{1} \mathrm{~J}_{\mathrm{CRh}}=74.2 \mathrm{~Hz}, \mathrm{CO}\right)$, $185.4\left(\mathrm{dd},{ }^{1} \mathrm{~J}_{\mathrm{CRh}}=52.5 \mathrm{~Hz},{ }^{3} \mathrm{~J}_{\mathrm{CP}}=10.4 \mathrm{~Hz}, \mathrm{CO}\right)$.

\section{Computational details}

All the geometries have been fully optimized at the B3LYP ${ }^{[26]}$ density functional level of calculation. The $6-31 \mathrm{G}(\mathrm{d})$ basis set has been used for main group elements. ${ }^{[27]}$ For Rh we have used the LANL2DZ basis set in which the inner electrons are represented by an effective core potential. ${ }^{[28]}$ Harmonic vibrational frequencies have been computed for all structures to verify that they correspond to energy minima (all frequencies are real). The stretching $\mathrm{CO}$ frequencies of complexes with $\mathrm{Rh}(\mathrm{CO})_{2} \mathrm{Cl}$ have been scaled by $0.9614 .^{[29]}$ The electronic structure of all systems has been analyzed using the NBO method. ${ }^{[30]}$ Wiberg bond indexes ${ }^{[31]}$ were computed within the NBO method. The structure of the triplet of $\mathbf{6} \mathbf{b}$ has been optimized using an unrestricted spin formalism. The reported $\mathrm{S} / \mathrm{T}$ energy gap includes the zero-point vibrational energy correction. Electrophilicities $(\omega)$ and maximum electronic charges $\left(\Delta N_{\max }\right)$ were calculated according to the definitions proposed by Parr, Yang et al.:

$$
\begin{aligned}
& \omega=\frac{\mu^{2}}{2 \eta} \\
& \Delta N_{\max }=-\frac{\mu}{\eta}
\end{aligned}
$$

where the corresponding chemical potentials $(\mu)$ and the hardnesses $(\eta)$ were computed within the ground-state parabola model ${ }^{[32]}$ according to the following approximate expressions related to the orbital energies of the Kohn-Sham frontier orbitals:

$$
\mu \approx(\varepsilon \mathrm{LUMO}+\varepsilon \text { HOMO }) / 2
$$$$
\eta \approx \varepsilon \text { LUMO - } \varepsilon \text { HOMO }
$$

All calculations have been done using the Gaussian-09 suite of programs. ${ }^{[33]}$

\section{Acknowledgements}

This work was supported by the CNRS and the Universite de Toulouse (UPS). This work was granted access to the HPC resources of CALMIP under the allocation 2012-P1225. Financial support from the Spanish Ministry of Economy and Competitiveness (CTQ2010-15408/BQU and CTQ201016959/BQU) and Generalitat de Catalunya (2009SGR-733), UPV/EHU (UFI QOSYC 11/22), and Basque Government (T67313) are gratefully acknowledged.

\section{Keywords: Carbene $\bullet$ vinylidenephosphorane $\bullet$ ligands •} phosphorus $\cdot$ ylides

[1] a) A. Igau, H. Grützmacher, A. Baceiredo, G. Bertrand, J. Am. Chem. Soc. 1988, 110, 6463; b) A. J. Arduengo, R. L. Harlow, M. Kline, J. Am. Chem. Soc. 1991, 113, 361 .

[2] a) W. Kirmse, Carbene Chemistry, 2nd ed.; Academic Press: New York, 1971; b) D. Bourissou, O. Guerret, F. P. Gabbai, G. Bertrand, Chem. Rev. 2000, 100, 39; c) Y. Canac, M. Soleilhavoup, S. Conejero, G. Bertrand, J. Organomet. Chem. 2004, 689, 3857; d) R. A. Moss, M. S. Platz, M. Jr Jones, Reactive Intermediate Chemistry, Eds. Wiley : New York, 2004 ; e) J. Vignolle, X. Cattoën, D. Bourissou, Chem. Rev. 2009, 109, 3333; f) O. Schuster, L. Yang, H. G. Raubenheimer, M. Albrecht, Chem. Rev. 2009, 109, 3445.

[3] a) S. P. Nolan, N-Heterocyclic Carbenes in Synthesis, Wiley-VCH: Weinheim, Germany, 2006; b) G. Bertrand (Ed.), Carbene Chemistry: From Fleeting Intermediates to Powerful Reagents, Marcel Dekker, New York, 2002; c) D. Martin, M. Melaimi, M. Soleilhavoup, G. Bertrand, Organometallics 2011, 30, 5304 .

[4] a) D. Enders, T. Balensiefer, Acc. Chem. Res. 2004, 37, 534; b) D. Enders , O. Niemeier, A. Henseler, Chem. Rev. 2007, 107, 5606; c) N. Marion, S. Díez-González, S. P. Nolan, S. P. Angew. Chem. Int. Ed. 2007, 46, 2988 d) A. Grossmann, D. Enders, Angew. Chem. Int. Ed. 2012, 51, 314; e) P. Chauhan, D. Enders, Angew. Chem. Int. Ed. 2014, 53, 1485.

[5] a) F. Glorius, N-Heterocyclic Carbenes in Transition Metal Catalysis, Vol. 21, (Eds.: F. Glorius), Springer Verlag, Berlin Heidelberg, 2006, p. 1; b) T. Kato, E. Maerten, A. Baceiredo, In Transition Metal Complexes of Neutral $\eta^{1}$-Carbon Ligands; Vol. 30, XI ed. (Eds.: R. Chauvin, Y. Canac), Springer Verlag, Berlin, 2010, p. 131. 
[6] S. Díez-González, S. P. Nolan, Coord. Chem. Rev. 2007, 251, 874.

[7] a) W. A. Herrmann, Angew. Chem. Int. Ed. 2002, 41, 1290; b) V. César S. Bellemin-Laponnaz, L. H. Gade, Chem. Soc. Rev. 2004, 33, 619; c) E. A. B. Kantchev, C. J. Brien, M. G. Organ, Angew. Chem. Int. Ed. 2007, 46 2768

[8] V. Lavallo, Y. Canac, A. DeHope, B. Donnadieu, G. Bertrand, Angew Chem. Int. Ed. 2005, 44, 7236

[9] a) S.-Y. Nakafuji, J. Kobayashi, T. Kawashima, Angew. Chem. Int. Ed. 2008, 47, 1141; b) J. Kobayashi, S. Nakafuji, A. Yatabe, T. Kawashima Chem. Commun. 2008, 4, 6233; c) M. Asay, B. Donnadieu, A. Baceiredo, M. Soleilhavoup, G. Bertrand, Inorg. Chem. 2008, 47, 3949; d) A. Fürstner, M. Alcarazo, K. Radkowski, C. W. Lehmann, Angew. Chem. Int. Ed. 2008 47, 8302.

[10] a) G. D. Frey, V. Lavallo, B. Donnadieu, W. W. Schoeller, G. Bertrand, Science 2007, 316, 439; b) V. Lavallo, B. Donnadieu, W. W. Schoeller, G. Bertrand, Angew. Chem. Int. Ed. 2006, 45, 3488; c) J. D. Masuda, W. W Schoeller, B. Donnadieu, G. Bertrand, Angew. Chem. Int. Ed. 2007, 46, 7052; d) O. Back, G. Kuchenbeiser, B. Donnadieu, G. Bertrand, Angew. Chem. Int. Ed. 2009, 48, 5530; e) C. D. Martin, C. M. Weinstein, C. E. Moore, A. L. Rheingold, G. Bertrand, Chem. Commun. 2013, 49, 4486.

[11] a) V. Lavallo, G. D. Frey, S. Kousar, B. Donnadieu, G. Bertrand, Proc. Natl. Acad. Sci. USA 2007, 104, 13569; b) V. Lavallo, G. D. Frey, B. Donnadieu, M. Soleilhavoup, G. Bertrand, Angew. Chem. Int. Ed. 2008, 47, 5224; c) M. Melaimi, M. Soleilhavoup, G. Bertrand, Angew. Chem. Int. Ed. 2010, 49,8810

[12] For a recent full article about carbene electrophilicity see: D. Martin, Y. Canac, V. Lavallo, G. Bertrand, J. Am. Chem. Soc. 2014, 136, 5023.

[13] a) T. W. Hudnall, C. W. Bielawski, J. Am. Chem. Soc. 2009, 131, 16039; b) T. W. Hudnall, J. P. Moerdyk, C. W. Bielawski, Chem. Commun. 2010 46, 4288; c) J. P. Moerdyk, C. W. Bielawski, Nature Chem. 2012, 4, 275.

[14] a) D. Martin, N. Lassauque, B. Donnadieu, G. Bertrand, Angew. Chem. Int Ed. 2012, 51, 6172; b) M. J. Lopez-Gomez, D. Martin, G. Bertrand, Chem. Commun. 2013, 49, 4483.

[15] a) H. J. Bestman, K. Roth, R. W. Rolf, Angew. Chem. 1977, 89, 915; b) M. Asay, T. Kato, N. Saffon-Merceron, F.Cossio, A. Baceiredo, G. Bertrand, Angew. Chem. Int. Ed. 2008, 47, 7530

[16] D. Enders, K. Breuer, G. Raabe, J. Runsink, J. H. Teles, J. P. Melder, K Ebel, S. Brode, Angew. Chem. Int. Ed. 1995, 34, 1021.

[17] For our recent contribution see of push-pull carbenes see: a) F. Lavigne E. Maerten, G. Alcaraz, N. Saffon-Merceron, C. Acosta-Silva, V. Branchadell, A. Baceiredo, J. Am. Chem. Soc. 2010, 132, 8864; b) F. Lavigne, E. Maerten, G. Alcaraz, V. Branchadell, N. Saffon-Merceron, A. Baceiredo, Angew. Chem. Int. Ed. 2012, 51, 2489; c) F. Lavigne, E. Maerten, G. Alcaraz, N. Saffon-Merceron, A. Baceiredo, Chem. Eur. J. 2014, 20, 297.

[18] A. Schmidpeter, W. Zeiss, Angew. Chem. Int. Ed. 1971, 10, 396

[19] C. C. Brown, C. Glotzbach, D. W. Stephan, Dalton Trans., 2010, 39, 9626.

[20] If $n \mathrm{BuLi}$ is used as base, nucleophilic addition of $n \mathrm{BuLi}$ to the imine function is observed (See supporting information for further details).
[21] Complete data are available in the supporting information.

[22] B. Lecea, M. Ayerbe ; A. Arrieta, F. P. Cossio, V. Branchadell, R. M. Ortuño, A. Baceiredo, J. Org. Chem. 2007, 72, 357.

[23] M. J. Menu, Y. Dartiguenave, M. Dartiguenave, A. Baceiredo, G. Bertrand, G. Phosphorus, Sulfur and Silicon 1990, 47, 327.

[24] a) M. Mayr, K. Wurst, K. H. Ongania, M. R. Buchmeiser, Chem. Eur. J. 2004, 10, 1256; b) C. Präsang, B. Donnadieu, G. Bertrand, J. Am. Chem. Soc. 2005, 127, 10182; c) R. A. III Kelly, H. Clavier, S. Giudice, N. M. Scott, E. D. Stevens, J. Bordner, I. Samardjiev, C. D. Hoff, L. Cavallo, S. P. Nolan Organometallics 2008, 27, 202.

[25] a) K. Denk, P. Sirsch, W. A. Herrmann, J. Organomet. Chem. 2002, 649, 219; b) D. Martin, A. Baceiredo, H. Gornitzka, W. W. Schoeller, G. Bertrand, Angew. Chem. Int. Ed. 2005, 44, 1700.

[26] a) A. D. Becke, J. Chem. Phys. 1993, 98, 5648; b) C. Lee, W. Yang, R.G Parr, Phys. Rev. B 1988, 37, 785 .

[27] W. J. Hehre, L. Radom, P. v. R. Schleyer, J. A. Pople, Ab Initio Molecular Orbital Theory; Wiley: New York, 1986.

[28] P. J. Hay, W. R. Wadt, J. Chem. Phys. 1985, 82, 270.

[29] A. P. Scott, L. Radom, J. Phys. Chem. 1996, 100, 16502.

[30] A.E. Reed, R. B. Weinstock, F. Weinhold, J. Chem. Phys. 1985, 83, 735

[31] K. B. Wiberg, Tetrahedron 1968, 24, 1083.

[32] a) R. G. Parr, W. Yang, Density Functional Theory of Atoms and Molecules, Oxford, New York 1989, pp 87-104; b) R. G. Parr, L. von Szentpály, S. Liu, J. Am. Chem. Soc. 1999, 121, 1922; c) L. von Szentpály, Chem. Phys. Lett. 1995, 245, 209; d) L. von Szentpály, J. Phys. Chem. A 1998, 102, 10912

[33] Gaussian 09, Revision C.01, M. J. Frisch, G. W. Trucks, H. B. Schlegel, G. E. Scuseria, M. A. Robb, J. R. Cheeseman, G. Scalmani, V. Barone, B Mennucci, G. A. Petersson, H. Nakatsuji, M. Caricato, X. Li, H. P. Hratchian, A. F. Izmaylov, J. Bloino, G. Zheng, J. L. Sonnenberg, M. Hada, M. Ehara, K. Toyota, R. Fukuda, J. Hasegawa, M. Ishida, T. Nakajima, Y. Honda, O. Kitao, H. Nakai, T. Vreven, J. A. Montgomery, Jr., J. E. Peralta, F. Ogliaro, M. Bearpark, J. J. Heyd, E. Brothers, K. N. Kudin, V. N. Staroverov, R. Kobayashi, J. Normand, K. Raghavachari, A. Rendell, J. C. Burant, S. S. lyengar, J. Tomasi, M. Cossi, N. Rega, J. M. Millam, M. Klene, J. E. Knox, J. B. Cross, V. Bakken, C. Adamo, J. Jaramillo, R. Gomperts, R. E. Stratmann, O. Yazyev, A. J. Austin, R. Cammi, C. Pomelli, J. W. Ochterski, R. L. Martin, K. Morokuma, V. G. Zakrzewski, G. A. Voth, P. Salvador, J. J. Dannenberg, S. Dapprich, A. D. Daniels, Ö. Farkas, J. B. Foresman, J. V. Ortiz, J. Cioslowski, D. J. Fox, Gaussian, Inc., Wallingford CT, 2009.

Received: ((will be filled in by the editorial staff))

Revised: ((will be filled in by the editorial staff)) Published online: ((will be filled in by the editorial staff)) 
Entry for the Table of Contents (Please choose one layout only)

Layout 1:

\section{FULL PAPER}

A novel family of cyclic push-pull carbenes, namely azavinylidene phosphoranes were synthesized by a formal [3+2] cycloaddition, followed by oxidation / deprotonation steps. Carbenes exhibit pronounced ambiphilic character (C-H insertion, cycloaddition reactions), confirmed by DFT calculations (S/T energy gap 24 $\left.\mathrm{kcal} . \mathrm{mol}^{-1}\right)$. In addition, they present excellent coordination abilities toward transition metals due to the cyclic structure.

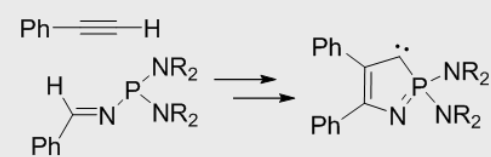

\section{Carbene Chemistry}

F. Lavigne, A. El Kazzi, Y. Escudié, E. Maerten, ${ }^{*}$ T. Kato, N. Saffon-Merceron, V. Branchadell, F. P. Cossío and A. Baceiredo*

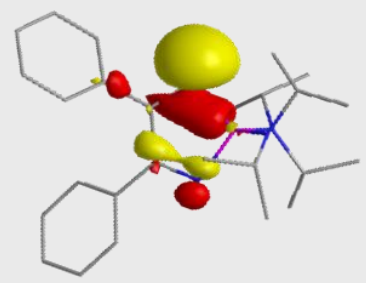

Azavinylidenephosphoranes: a new class of cyclic push-pull carbenes 